\title{
$N$-Heterocycles Scaffolds as Quorum Sensing Inhibitors. Design, Synthesis, Biological and Docking Studies
}

\author{
Alfredo Fuentes-Gutiérrez ${ }^{1}$, Everardo Curiel-Quesada ${ }^{2}$, José Correa-Basurto ${ }^{3}$, \\ Alberto Martínez-Muñoz ${ }^{3}$ and Alicia Reyes-Arellano ${ }^{1, *}$ \\ 1 Departamento de Química Orgánica, Escuela Nacional de Ciencias Biológicas del Instituto Politécnico \\ Nacional (ENCB-IPN), Ciudad de México 11340, Mexico; alfredfg@hotmail.com \\ 2 Departamento de Bioquímica, Escuela Nacional de Ciencias Biológicas del Instituto Politécnico \\ Nacional (ENCB-IPN), Ciudad de México 11340, Mexico; ecqmixcoacdf@gmail.com \\ 3 Laboratorio de Diseño y Desarrollo de Nuevos Fármacos e Innovación Biotecnológica, Sección de Estudios \\ de Posgrado e Investigación, Escuela Superior de Medicina del Instituto Politécnico Nacional, \\ Ciudad de México 11340, Mexico; corrjose@gmail.com (J.C.-B.); albert.wsker@gmail.com (A.M.-M.) \\ * Correspondence: areyesarellano@yahoo.com.mx; Tel.: +52-55-57-29-6000 (ext. 62526)
}

Received: 2 October 2020; Accepted: 10 December 2020; Published: 14 December 2020

\begin{abstract}
Quorum sensing is a communication system among bacteria to sense the proper time to express their virulence factors. Quorum sensing inhibition is a therapeutic strategy to block bacterial mechanisms of virulence. The aim of this study was to synthesize and evaluate new bioisosteres of $N$-acyl homoserine lactones as Quorum sensing inhibitors in Chromobacterium violaceum CV026 by quantifying the specific production of violacein. Five series of compounds with different heterocyclic scaffolds were synthesized in good yields: thiazoles, 16a-c, thiazolines 17a-c, benzimidazoles 18a-c, pyridines 19a-c and imidazolines 32a-c. All 15 compounds showed activity as Quorum sensing inhibitors except 16a. Compounds $16 b, 17 a-c, 18 a, 18 c, 19 c$ and $32 b$ exhibited activity at concentrations of $10 \mu \mathrm{M}$ and $100 \mu \mathrm{M}$, highlighting the activity of benzimidazole $18 \mathbf{a}\left(\mathrm{IC}_{50}=36.67 \mu \mathrm{M}\right)$ and $32 \mathbf{b}$ $\left(\mathrm{IC}_{50}=85.03 \mu \mathrm{M}\right)$. Pyridine $19 \mathrm{c}$ displayed the best quorum sensing inhibition activity $\left(\mathrm{IC}_{50}=9.66 \mu \mathrm{M}\right)$. Molecular docking simulations were conducted for all test compounds on the Chromobacterium violaceum $\mathrm{CviR}$ protein to gain insight into the process of quorum sensing inhibition. The in-silico data reveal that all 15 the compounds have higher affinity for the protein than the native AHL ligand (1). A strong correlation was found between the theoretical and experimental results.
\end{abstract}

Keywords: heterocycles synthesis; new AHL bioisosteres; $\pi-\pi$ interactions; quorum sensing

\section{Introduction}

Quorum sensing (QS), a mechanism of cell-to-cell communication in bacteria and fungi, involves self-produced chemical signals called autoinducers that function as semiochemicals [1]. Bacteria use this mechanism to communicate among themselves through the recognition and measurement of extracellular autoinducers, which accumulate in the local environment until reaching a certain level. At such a point, the bacterial population is sufficient to allow for group actions and therefore signaling pathways are activated and specific genes (some related to virulence factors) are transcribed [2-5].

Since the disruption of QS could plausibly attenuate or halt bacterial virulence and overcome bacterial resistance, it is an attractive target for drug discovery [6,7]. In Gram-negative bacteria the autoinducers for QS are $N$-acyl homoserine lactones (AHLs 1). They are synthesized and released to the extracellular medium, diffuse freely through the bacterial membrane, and bind to specific cytoplasmic receptors. Once reaching a certain level, AHLs 1 promote specific gene expression 
responsible for bioluminescence [8], pigment production [9], toxin production [10], and the regulation of the expression of virulence factors such as biofilm formation [4-6]. It is particularly important to discover and implement an effective strategy for controlling Gram-negative bacteria due to their role in hospital-acquired infections and their increasing resistance to numerous drugs [6,11].

One of the most common strategies used to interfere with QS is the antagonism of AHL signaling by organic molecules [7]. Accordingly, researchers have developed bioisosteres of AHL (although they are not always designated as such), most of which are monovalent bioisosteres and act as antagonists [12,13]. Thus, the use of AHL as a lead compound has led to the development of a variety of QS inhibitors (QSIs) (Figure 1). The inhibition of QS has been achieved in Chromobacterium violaceum by a set of $N$-substituted homocysteine thiolactones (2-5) [14], in Pseudomonas aeruginosa by AHL bioisosteres based on indole (6-7) [15], in Vibrio fischeri by a N-(2-nitrophenyl)-amide scaffold (8-9) as an AHL bioisosteres [16], in C. violaceum and P. aeruginosa by a set of AHL bioisosteres (10-13) by modifying the acyl side chain [17], and in P. aeruginosa by a set of AHL bioisosteres based on the itaconimide scaffold (14-15) [18].<smiles>[R]c1cc(Cl)ccc1OCCCC(=O)N[C@H]1CCSC1=O</smiles>

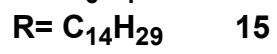<smiles>[R]SC(=O)NC1CCOC1=O</smiles>

$R=$ 4-chlorophenyl, $n=1 \quad 10$ $\mathrm{R}=$ 2-benzothiazolyl, $\mathrm{n}=1 \quad 11$ $\mathrm{R}=4$-chlorophenyl, $\mathrm{n}=2 \quad 12$ $R=2$-benzothiazolyl, $n=2 \quad 13$<smiles>[R]c1cccc(OCCCC(=O)N[C@H]2CCSC2=O)c1</smiles>

$\mathrm{R}=\mathrm{Cl} 4$ $\mathrm{R}=\mathrm{Br} 5$<smiles>[R]C([R])CC(=O)N[C@H]1CCNC1=O</smiles>

AHL 1 $\mathbf{R}_{\mathbf{1}}=\mathrm{H}, \mathrm{OH},=\mathrm{O}$ $\mathbf{R}_{\mathbf{2}}=$ Aliphatic chain<smiles>[R]C(=O)Nc1c(-c2ccccc2)[nH]c2ccccc12</smiles>

$\mathrm{R}=\mathrm{C}_{5} \mathrm{H}_{11} \quad 6$<smiles>[R]C(=O)Nc1ccc2[nH]c(C)cc2c1</smiles><smiles>[R]C=[R]([H])C[R]</smiles>

$$
R=C_{11} H_{23} 7
$$

Figure 1. AHL and some known bioisosteres.

After synthesizing AHL bioisosteres, it is important to demonstrate their capacity to inhibit QS. An excellent model for this purpose is Chromobacterium violaceum due to it is a QS biosensor [19]. The aim of the present study was to synthesize new bioisosteres of AHL and evaluate them in C. violaceum CV026 as QSIs by quantifying the specific production of violacein. Five series of compounds were synthesized, each containing a distinct heterocyclic scaffold in its structure: thiazoles $(\mathbf{1 6 a}-\mathbf{c})$, thiazolines $(\mathbf{1 7 a} \mathbf{a}-\mathbf{c})$, benzimidazoles $(\mathbf{1 8 a}-\mathbf{c})$, pyridines $(19 \mathbf{a}-\mathbf{c})$ and imidazolines $(32 \mathbf{a}-\mathbf{c})$ to be assayed experimentally. Finally, molecular docking simulations were conducted for all 15 test compounds on C. violaceum CviR protein to provide insights into the process of QS inhibition. 


\section{Results and Discussion}

\subsection{Bioisosteres Design}

New non-classical bioisosteres [12] of AHL were designed by modifying hexanoyl homoserine lactone 1 (i.e., $\mathrm{R}_{1}=\mathrm{H}, \mathrm{R}_{2}=\mathrm{C}_{3} \mathrm{H}_{7}$ ), an autoinducer of Chromobacterium violaceum. Specifically, the lactone ring 1 was bioisosterically replaced by heterocyclic rings of thiazoles (16a-c), thiazolines (17a-c), benzimidazoles $(\mathbf{1 8 a}-\mathbf{c})$, pyridines $(\mathbf{1 9 a}-\mathbf{c})$ and imidazolines (32a-c) (Figure 2). The lactone ring has been previously substituted by other heterocycles and even phenyl (Figure 1) [14-18]. Furthermore there are reports of its replacement with cyclopentane, cyclopentanol, cyclopentanone, oxazolidinone, benzothiazol and thiadiazol [13]. Our group reported a substitution with imidazoline and oxazoline in prior studies $[20,21]$. In the design of the present bioisosteres, the amido group and the lateral chain were conserved but the length of the latter varied. Additionally, an aromatic ring was included in all the molecules to promote $\pi-\pi$ interactions with the receptor. Thus, five series of compounds emerged (Figure 2).<smiles>[R]C(=O)Nc1nc(C(=O)OCC)cs1</smiles>

16 a) $-\mathrm{C}_{3} \mathrm{H}_{7}$

b) $-\mathrm{C}_{5} \mathrm{H}_{11}$

c) $-\mathrm{C}_{7} \mathrm{H}_{15}$<smiles>[R]C(=O)Nc1ccc(C2=NCCS2)cc1</smiles>

17<smiles>[R]NC(=O)CSc1nc2ccc(Cl)cc2[nH]1</smiles>

18

a) $-\mathrm{C}_{6} \mathrm{H}_{4}-3-\mathrm{Cl}$

b) $-\mathrm{CH}_{2}-\mathrm{C}_{6} \mathrm{H}_{4}-4-\mathrm{Cl}$<smiles>[R]Sc1nc2ccc(Cl)cc2[nH]1</smiles>

18

c) $-\mathrm{C}_{9} \mathrm{H}_{19}$<smiles>[R]C(=O)Nc1ccc(Cl)cn1</smiles>

19

a) $-\mathrm{C}_{3} \mathrm{H}_{7}$

b) $-\mathrm{C}_{5} \mathrm{H}_{11}$

c) $-\mathrm{C}_{8} \mathrm{H}_{17}$

b) $-\mathrm{C}_{5} \mathrm{H}_{11}$

c) $-\mathrm{C}_{7} \mathrm{H}_{15}$

Figure 2. AHL bioisosteres design presently.

Thiazoles 16a-c. Although compounds 16 contain two structural elements (an amido group and a lateral chain) similar to hexanoyl homoserine lactone 1, they are non-classical bioisosteres [12], formed by exchanging one functional group with another (i.e., lactone with pyridine). The ester group could have been removed, but it was left in place to observe the effect.

Thiazolines 17a-c. The phenyl ring in these compounds serves both as a linker and the aromatic factor required in the design.

Benzimidazoles 18a-c. The aim with this series was to combine a fragment-based QSI design [22] with a bioisosteric substitution of the lactone ring of AHL by a benzimidazole ring. Thioacetamide is a fragment in a compound reported to have good activity as a QSI [23], furthermore the thioacetamide group could be considered a retroisoster [12] of the amido group of AHL. In the case of 18a-b, the lateral chain was replaced by a phenyl ring, which was 3-Cl-phenyl for 18a and 4-Cl-benzyl for 18b. The amido 
group of 18c was substituted by a sulfur, and the nonyl chain was left in place since it has worked well in other bioisosteres [24].

Pyridines 19a-c. Although the pyridines contain two elements of AHL, they are regarded as non-classical bioisosteres because the pyridine ring is completely different from the lactone ring. Consequently, they are based on an exchange of one functional group for another [12].

\subsection{Synthesis}

\subsubsection{Synthesis of 2-Acylamino-thiazole-4-carboxylic Acid Ethyl Esters (16a-c)}

The synthesis of 16a-c began with the formation of amino thiazole 22, utilizing thiourea and ethyl bromopyruvate as raw materials (Scheme 1).<smiles>CCOC(=O)C(=O)CBr</smiles>

20<smiles>NC(N)=S</smiles>

21

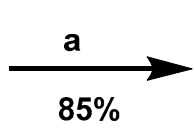

$85 \%$

Scheme 1. Synthetic route to obtain the $N$-(thiazol-2-yl)-amine (22). Reagents and conditions: a: EtOH, $\mathrm{rt}, 16 \mathrm{~h}$.

To obtain 2-amine thiazol 22, Hantzsch synthesis was carried out with an $\alpha$-halo carbonyl compound, $\alpha$-bromo ethyl pyruvate (20) and thiourea as raw materials and $\mathrm{EtOH}$ as solvent according to the methodology published by Kaushik [25]. The reaction mixture was stirred for $16 \mathrm{~h}$ at room temperature (rt), furnishing the desired product in good yields. (Scheme 1.) Subsequently, intermediary 22 was acylated with the corresponding carboxylic acid, a reaction described by various authors [26-29]. Such a reaction occurs in 2-amine thiazole with electron with drawing groups in position 4, for which heterogeneous yields have been documented in the literature. For instance, low yields (17-47\%) were provided when Parish performed the acylation reaction with acyl chlorides in the presence of bases [26]. The acylation reaction has also been carried out with carboxylic acids and coupling reagents CDI or EDCI, affording moderate to good yields (54-69\%) [27]. Considering, this background, distinct conditions were herein investigated but two procedures were followed: MW energy, as reported by You [28], and DCC as a coupling reagent with conventional heating as the energy source [29] (Table 1).

Table 1. Results from the synthesis of thiazoles $16 a-c$.

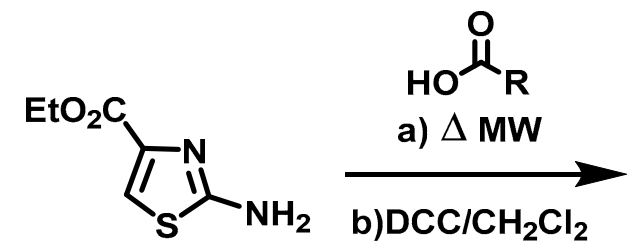

22

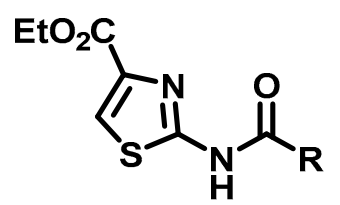

16

\begin{tabular}{cccccc}
\hline Experiment & $\mathbf{R}$ & Thiazole & Procedure & Temperature $\left({ }^{\circ} \mathbf{C}\right)$ & Yield (\%) \\
\hline 1 & $-\mathrm{C}_{3} \mathrm{H}_{7}$ & $\mathbf{1 6 a}$ & $\mathrm{A}$ & 150 & 82 \\
\hline 2 & $-\mathrm{C}_{3} \mathrm{H}_{7}$ & $\mathbf{1 6 a}$ & $\mathrm{B}$ & $\mathrm{rt}$ & 12 \\
\hline 3 & $-\mathrm{C}_{5} \mathrm{H}_{11}$ & $\mathbf{1 6 b}$ & $\mathrm{A}$ & 150 & 85 \\
\hline 4 & $-\mathrm{C}_{5} \mathrm{H}_{11}$ & $\mathbf{1 6 b}$ & $\mathrm{B}$ & $\mathrm{rt}$ & 20 \\
\hline 5 & $-\mathrm{C}_{7} \mathrm{H}_{15}$ & $\mathbf{1 6}$ & $\mathrm{A}$ & 180 & 80 \\
\hline
\end{tabular}

Conditions: (A) 2-amine thiazole (1 eq), carboxylic acid (2 mL), $90 \mathrm{~min}$. (B) 2-amine thiazole (1 eq), DCC (1 eq), carboxylic acid (1 eq), $\mathrm{CH}_{2} \mathrm{Cl}_{2}(20 \mathrm{~mL}), \mathrm{N}_{2}$ atmosphere, $16 \mathrm{~h}$. 
Data in the literature [27] indicate that the acylation reaction of compounds like 22 depends on the coupling reagents, the solvent and the mixture of these two factors. Additionally, it is necessary to consider the low nucleophilicity of the amine group conjugated to an electron withdrawing group. When Toyoshima [30] carried out the synthesis of compounds 16, the yields were lower than those found presently. In the acylation reaction of an amine, the excess concentration of the acid is important due autocatalysis [31]. Compounds $\mathbf{1 6}$ have been tested as antivirals and anti-tuberculosis drugs [30] but never as QSIs.

\subsubsection{Synthesis of $N$-[4-(Thiazolin-2-yl)-phenyl]-amides (17a-c)}

The synthetic pathway began with the reaction between 4-amino benzonitrile and cysteamine hydrochloride to prepare intermediate 25.

To obtain 25, 4-amine benzonitrile and cysteamine hydrochoride were reacted by using EtOH: $\mathrm{H}_{2} \mathrm{O}$ 1:1 as solvent (Table 2).

Table 2. Results obtained to achieve 4-(4'5'-dihydrothiazol-2-yl) aniline 25.

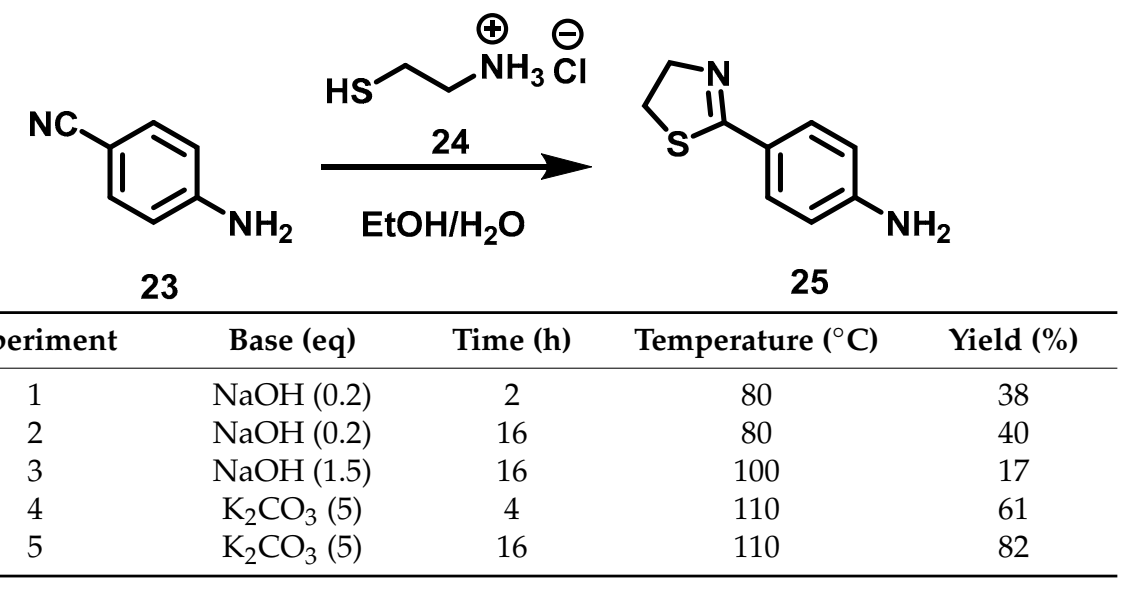

Conditions: 4-amine benzonitrile, (1 eq), cysteamine hydrochloride (1.5 eq), EtOH/ $\mathrm{H}_{2} \mathrm{O}$ 1:1 (5 mL).

Cazin conditions [32] provided a low yield for 25 (Table 2, experiment 1), observing an incomplete reaction. Lengthening the reaction time (experiment 2) did not improve the outcome, nor did a greater amount of base (experiment 3), which caused the yield to drop sharply due to the hydrolysis of benzonitrile to carboxylic acid. The combination of a weaker base $\left(\mathrm{K}_{2} \mathrm{CO}_{3}\right.$ instead of $\left.\mathrm{NaOH}\right)$ and a higher reaction temperature, as described by Hintermann [33], gave better results (experiment 4). Since the raw material was detected in TLC, the reaction time was increased (experiment 5), leading to a high yield with the complete reaction of the raw material.

It is known that the transformation of benzonitrile to thiazoline was established in accordance with the computational studies by Mor and Cavalli [34], (Figure 3).

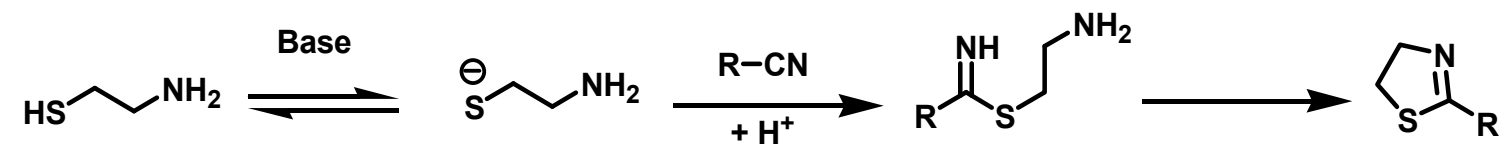

Figure 3. Transformation of benzonitriles to 2-thiazolines.

The synthesis of $\mathbf{1 7}$ was completed by an acylation reaction of $\mathbf{2 5}$ with the corresponding carboxylic acids. Two possibilities were taken into account when planning the synthetic route of $\mathbf{1 7}$ : the acylation of amine thiazole 22 and the acylation of anilines, the latter frequently reported. The different conditions that have been adopted for the amine acylation reaction include carbodiimides as coupling reagents [26,27], $\mathrm{MW}$ and $\mathrm{SiO}_{2}$ [35], zeolitas as catalyst [31] and transamidation with zirconocene 
dichloride [36]. The methodology chosen, based on the acylation of thiazole 22 (Table 3), furnished the novel thiazolines $\mathbf{1 7} \mathbf{a}-\mathbf{c}$ in good yields.

Table 3. Synthesis of thiazolines $17 \mathbf{a}-\mathbf{c}$.<smiles>Nc1ccc(C2=NCCS2)cc1</smiles>

25

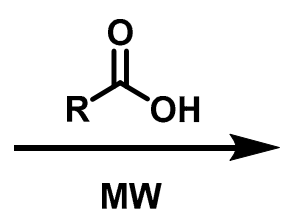

MW<smiles>[R]C(=O)Nc1ccc(C2=NCCS2)cc1</smiles>

17

a) $\mathrm{C}_{3} \mathrm{H}_{7}$

b) $\mathrm{C}_{5} \mathrm{H}_{11}$

c) $\mathrm{C}_{7} \mathrm{H}_{15}$

\begin{tabular}{ccccc}
\hline Experiment & $\mathbf{R}$ & Compound & Temperature $\left({ }^{\circ} \mathbf{C}\right)$ & Yield (\%) \\
\hline 1 & $-\mathrm{C}_{3} \mathrm{H}_{7}$ & $\mathbf{1 7 a}$ & 150 & 82 \\
2 & $-\mathrm{C}_{5} \mathrm{H}_{11}$ & $\mathbf{1 7 b}$ & 150 & 85 \\
3 & $-\mathrm{C}_{7} \mathrm{H}_{15}$ & $\mathbf{1 7 c}$ & 180 & 80 \\
\hline
\end{tabular}

Conditiones: 4-(thiazolin-2-yl)aniline (1 eq), carboxylic acid ( $2 \mathrm{~mL}), 90 \mathrm{~min}$.

\subsubsection{Synthesis of 6-Chloro-2-alkylsulfanyl-1H-benzimidazoles (18a-c)}

The two-step synthetic procedure to obtain benzimidazoles 18a-c (Scheme 2) began with the reaction between carbon disulfide and 4-chloro-1,2-phenylenediamine 26 to afford 5-chloro-benzimidazole-2-thione 27 [37] (Tabla 4).<smiles>Nc1ccc(Cl)cc1N</smiles>

26

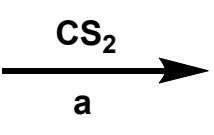

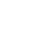<smiles>S=c1[nH]c2ccc(Cl)cc2[nH]1</smiles>

27

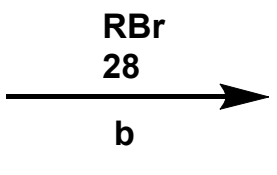

Cl

18

$R=\quad a)$<smiles>CC(C)(C)C(=O)Nc1cccc(Cl)c1</smiles>

b)<smiles>CC(C)(C)C(=O)NCc1ccc(Cl)cc1</smiles>

c)

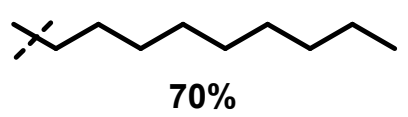

Scheme 2. Synthetic procedure to obtain the 6-chloro-2-alkylsulfanyl- $1 \mathrm{H}$-benzimidazoles $(\mathbf{1 8 a}-\mathbf{c})$. Reagents and conditions: a: potassium hydroxide, $\mathrm{EtOH} / \mathrm{H}_{2} \mathrm{O}(7: 3), 80^{\circ} \mathrm{C}, 5 \mathrm{~h}$; b: $\mathrm{EtOH}, 60^{\circ} \mathrm{C}, 16 \mathrm{~h}$. (Table 4).

To prepare intermediary $\mathbf{2 7}$, variations in the conditions were based on previous reports [37]. 
Table 4. Synthesis of 5-chloro-1,3-dihidro-2H-benzo[d]imidazole-2-thione 27.<smiles>Nc1ccc(Cl)cc1N</smiles>

26

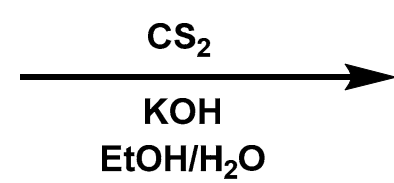

$80^{\circ} \mathrm{C}$<smiles>S=c1[nH]c2ccc(Cl)cc2[nH]1</smiles>

27

\begin{tabular}{cccc}
\hline Assay & Energy & Time (h) & Yield (\%) \\
\hline 1 & Conventional & 3 & 52 \\
2 & MW & 3 & 24 \\
3 & Conventional & 5 & 88 \\
\hline
\end{tabular}

Reactions conditions: Phenylenediamine (1 eq), $\mathrm{CS}_{2}(1.3 \mathrm{eq}), \mathrm{KOH}(3 \mathrm{eq}), \mathrm{EtOH} / \mathrm{H}_{2} \mathrm{O}$ 7:3 (5 mL), $80{ }^{\circ} \mathrm{C}$.

Experiment 1 was carried out under the conditions described by Micheva [37], who obtained very good yields at $3 \mathrm{~h}$ of reaction. In our hands, however, the outcome was different, detecting the presence of phenylenediamine after $3 \mathrm{~h}$ (experiment 1). A change to MW energy (experiment 2) was also unsuccessful. By using conventional energy and increasing the reaction time from 3 to $5 \mathrm{~h}$ (experiment 3 ), the total consumption of raw material was observed and thione 27 was produced in a higher yield. In accordance with the work of Sartori [38], the proposed reaction sequence is the formation of ethyl(2-amino-5-chlorophenyl)carbamothioate 29 followed by its conversion into isothiocyanonitrile $\mathbf{3 0}$ and finally into thione $\mathbf{2 7}$ (Scheme 3).

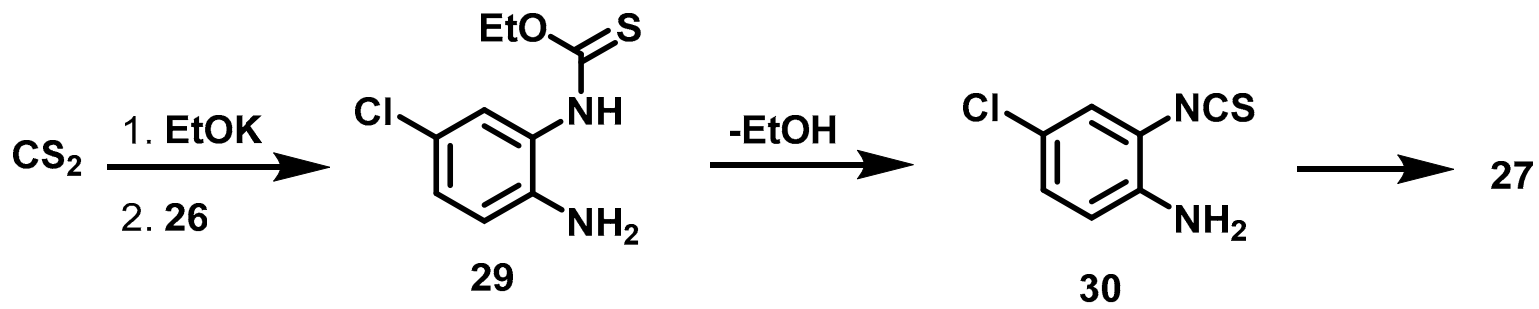

Scheme 3. Synthetic route of thione 27 by transformation of $4-\mathrm{Cl}$ phenylenediamine 26 with carbamothiate 29.

This intermediate 27 was then subjected to an acylation reaction [25] with the bromoacetamides $\mathbf{2 8 a} \mathbf{2 8 b}$ or alkylation with $n$-bromononane $\mathbf{2 8 c}$, to obtain $\mathbf{1 8} \mathbf{a}-\mathbf{c}$, Scheme 3 . Bromoacetamides $\mathbf{2 8 a} \mathbf{a}-\mathbf{b}$ were synthesized with 2-bromo acetyl bromide and 3-Cl aniline 31 or 4- $\mathrm{Cl}$ benzylamine 32 (Scheme 4).

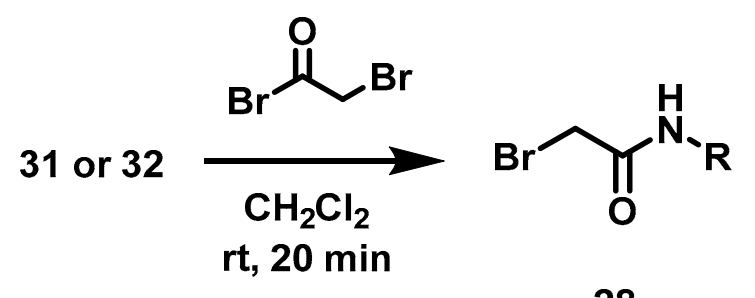

28

Scheme 4. Synthesis of bromoacetamides 28.

Finally 28 were reacted with $\mathbf{2 7}$ to achieve 18a-c. Scheme 2. There are reports of benzimidazole acetamides as antidiabetic drugs [39], antimicrobial agents [40], and QSI in P. aeruginosa [41]. However, benzimidazoles 18 are new compounds that open a broad range of opportunities for research into QSIs. 


\subsubsection{Synthesis of $N$-(5-Chloro-pyridin-2-yl)-amides (19a-c)}

Compounds $19 \mathrm{a}-\mathbf{c}$ were synthesized by the acylation of 5-chloro-2-amino pyridine 33 under the same reaction conditions as for $\mathbf{1 7 a}-\mathbf{c}$ and $\mathbf{1 8 a}-\mathbf{c}$. The $N$-(5-chloro-pyridin-2-yl)-amides 19 were generated in excellent yields (87-91\%) (Table 5).

Table 5. Synthesis of 5-chloropyridin-2-yl)alkylamides 19.

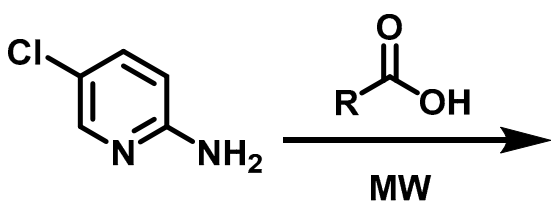

33<smiles>[R]C(=O)Nc1ccc(Cl)cn1</smiles>

19

\begin{tabular}{ccccc}
\hline Experiment & $\mathbf{R}$ & Compound & Temperature $\left({ }^{\circ} \mathbf{C}\right)$ & Yield (\%) \\
\hline 1 & $-\mathrm{C}_{3} \mathrm{H}_{7}$ & $\mathbf{1 9 a}$ & 150 & 91 \\
2 & $-\mathrm{C}_{5} \mathrm{H}_{11}$ & $\mathbf{1 9 b}$ & 150 & 87 \\
3 & $-\mathrm{C}_{8} \mathrm{H}_{17}$ & $\mathbf{1 9 c}$ & 180 & 90 \\
\hline
\end{tabular}

Conditions: 5-chloropyridine-2-amine (1 eq), carboxylic acid (2 mL), $90 \mathrm{~min}$.

Although compounds 19 are known and their use has been reported [42,43], their possible application as QSIs is unexplored. Characterization of pyridines 19 was not found.

\subsubsection{Synthesis of $N$-Substituted-2-[4-(imidazolin-2-yl)-phenoxy]-acetamides (32a-c)}

In addition to designing bioisosters 16-19, three other novel imidazoline acetamides were synthesized $(32 \mathbf{a}-\mathbf{c})$ because of the similarity of their structure to that of imidazoline, the QS inhibitory activity of which is well recognized [20]. Moreover, their structural elements coincide with those considered presently. In a previous theoretical study, the $\Delta \mathrm{G}$ of the complexes formed by $\mathbf{3 2 a}-\mathbf{c}$ and the CviR protein were calculated, finding much lower values than for the complex of AHL with the same protein [44].

Based on the method described by our group [20], imidazolines 32 were synthesized with different substituents on the amide group. Obtaining compounds 32 began with the synthesis of the aldehydes 35 , for this it was necessary to obtain acetamide $\mathbf{3 4}$ (Scheme 5).

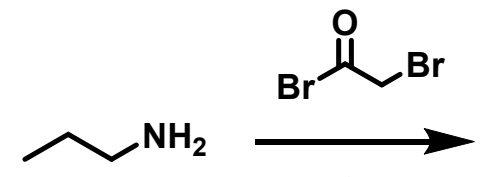

a

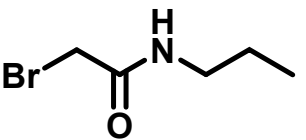

34

Scheme 5. Procedure to synthesize $\alpha$-bromo- $N$-propylacetamide 34. Conditiones: a. Amine (1 eq), bromoacetyl bromide (1.2 eq), $\mathrm{CH}_{2} \mathrm{Cl}_{2}(15 \mathrm{~mL}), \mathrm{rt}, 20 \mathrm{~min}$.

To prepare aldehydes 35, a previous report was considered [20] (Table 6). 
Table 6. Results from the synthesis of aldehydes 35.

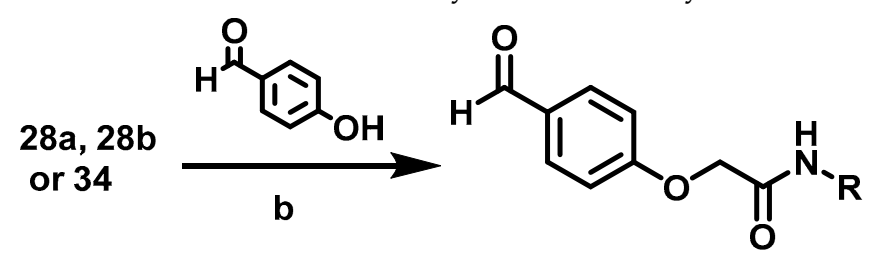

\begin{tabular}{ccccc} 
& \multicolumn{5}{c}{35} \\
\hline Experiment & $\mathbf{R}$ & Compound & Time (h) & Yield (\%) \\
\hline 1 & $-\mathrm{C}_{6} \mathrm{H}_{4}-3-\mathrm{Cl}$ & $35 \mathbf{a}$ & $18^{20}$ & 63 \\
2 & $-\mathrm{C}_{6} \mathrm{H}_{4}-3-\mathrm{Cl}$ & $35 \mathbf{a}$ & 6 & 65 \\
3 & $-\mathrm{CH}_{2}-\mathrm{C}_{6} \mathrm{H}_{4}-4-\mathrm{Cl}$ & $35 \mathbf{b}$ & 6 & 73 \\
4 & $-\mathrm{C}_{3} \mathrm{H}_{7}$ & $35 \mathrm{c}$ & 6 & 79 \\
\hline
\end{tabular}

Conditiones: amide (1 eq), 4-hydroxybenzaldehyde (1.1 eq), DBU (1 eq), acetonitrile (20 mL).

Compared to the report on the preparation of aldehyde 35a, a shorter time was herein achieved (Table 6) by using 2-bromoacetyl bromide rather than the previously employed $\alpha$-bromoacetic acid and DCC [20]. Compounds 35 were subjected to cyclization with ethylenediamine and subsequent oxidation with NBS under ultrasound irradiation, as reported by Torres [29]. The corresponding imidazolines 32a-c were provided in good yields (85-90\%) (Scheme 6).

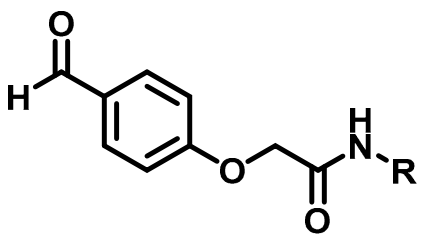

35

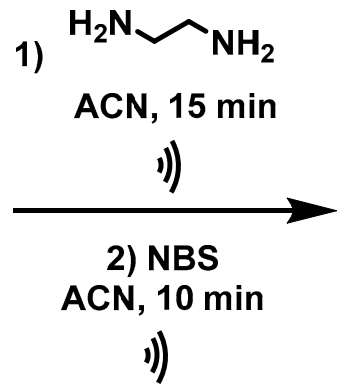

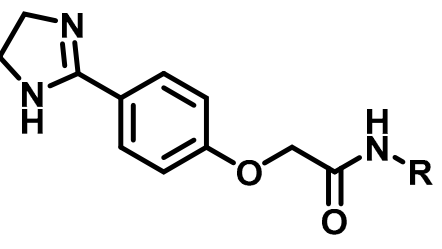

32
a) $\mathrm{R}=-\mathrm{C}_{6} \mathrm{H}_{4}-3-\mathrm{Cl}$
b) $\mathrm{R}=-\mathrm{CH}_{2}-\mathrm{C}_{6} \mathrm{H}_{4}-4-\mathrm{Cl}$
c) $\mathrm{R}=-\mathrm{C}_{3} \mathrm{H}_{7}$
a) $\mathrm{R}=-\mathrm{C}_{6} \mathrm{H}_{4}-3-\mathrm{Cl}$
$88 \%$
b) $\mathrm{R}=-\mathrm{CH}_{2}-\mathrm{C}_{6} \mathrm{H}_{4}-4-\mathrm{Cl}$
$90 \%$
c) $\mathrm{R}=-\mathrm{C}_{3} \mathrm{H}_{7}$
$85 \%$

Scheme 6. Synthetic procedure to obtain the imidazoline acetamides (32a-c). Reagents and conditions: (a) $\mathrm{CH}_{2} \mathrm{Cl}_{2}, \mathrm{rt}, 20 \mathrm{~min}$; (b) $\mathrm{DBU}, \mathrm{ACN}, 70{ }^{\circ} \mathrm{C}, 8 \mathrm{~h}$; (c) ethylenediamine, $\left.\mathrm{ACN}, 1\right)$, $15 \mathrm{~min}$; then NBS,

$\mathrm{ACN}, 10 \mathrm{~min}$.

\subsection{Characterization of Compounds}

All compounds were characterized by spectroscopic methods utilizing IR, NMR, and DIP-MS. Spectra were assigned with the help of heteronuclear correlation (gHSQC, gHMBC) and in some cases with homonuclear correlation (gCOSY). Mass spectra were recorded with positive and negative ions. Spectra for all compounds are attached in the Supplementary Materials (Figures S1-S104).

\section{Evaluation of QS Inhibition on Chromobacterium violaceum CV026}

The synthesized compounds were added (at 10, 100 and $1000 \mu \mathrm{M}$ ) to the bacteria (OD600 of 0.12) in thioglycolate broth supplemented with C6-AHL, followed by incubation for $16 \mathrm{~h}$. The determination of the specific production of violacein, calculated as the ratio of detectable pigment (OD577) per amount of bacteria (OD720), demonstrated the existence of QS inhibitory activity for almost all test compounds. (Figures 4-8). There is a clear difference between quorum sensing and antibacterial activity. In this 
research, growth inhibition by the evaluated heterocycles results in a decrease in OD720. While this decrease was statistically significant, taking cultures grown in the absence of inhibitors as a basis of comparison, this is denoted with a letter ' $a$ ' on the top of the corresponding bar and stated as ' $a$ ' the footnote of the figure.

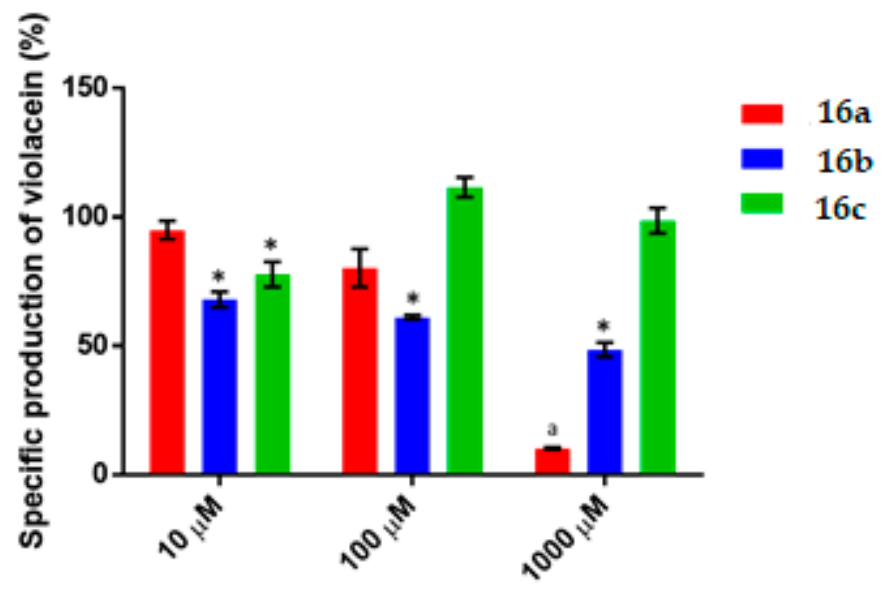

Concentration<smiles>CCCC(=O)Nc1nc(C(=O)OC)cs1</smiles>

16 a<smiles>CCCCCC(=O)Nc1nc(C(=O)OC)cs1</smiles>

$16 \mathrm{~b}$<smiles>CCCCCCCC(=O)Nc1nc(C(=O)OC)cs1</smiles>

$16 \mathrm{c}$

Figure 4. Specific production of violacein by Chromobacterium violaceum CV026 in the presence of the thiazoles (16a-c) at 10,100 and $1000 \mu \mathrm{M}$. Data are expressed as a percentage of the specific production of violacein (mean $\pm \mathrm{SEM}$ ) and normalized by considering the value without the addition of a compound as $100 \%$. Significance was confirmed by the Student's $t$-test with an accuracy of ${ }^{*} p<0.05$ at the marked bars. ${ }^{\text {a }}$ Denotes an antimicrobial effect of the compound. Experiments were performed with $n=6$.

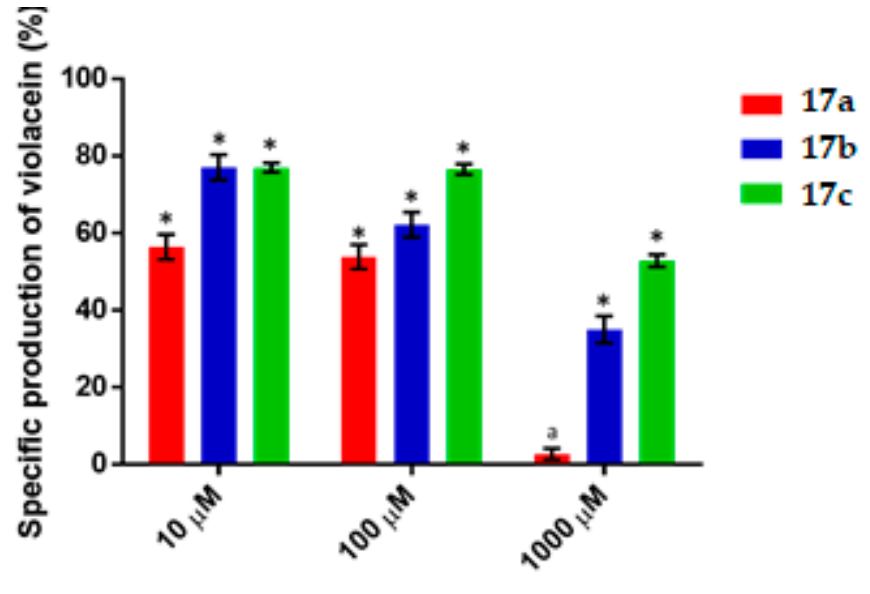

Concentration<smiles>CCCC(=O)Nc1ccc(C2=NCCS2)cc1</smiles>

$17 \mathrm{a}$<smiles>CCCCCC(=O)Nc1ccc(C2=NCCS2)cc1</smiles>

$17 \mathrm{~b}$

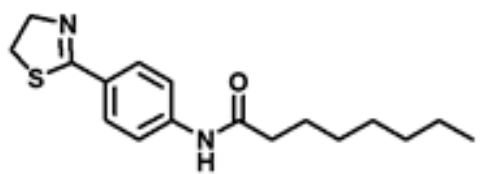

17c

Figure 5. Violacein specific production by Chromobacterium violaceum CV026 in the presence of the synthesized thiazolines at 10,100 and $1000 \mu \mathrm{M}$ concentrations. Data are expreseed as the percentage of the specific production of violacein (mean \pm SEM) and normalized on the violacein production without compound addition and this was considered as $100 \%$. Significance was confirmed by the Student's $t$-test with an accuracy of ${ }^{*} p<0.05$ at the marked bars; ${ }^{\text {a }}$ represents antimicrobial effect of the tested compound. Experiments were performed with $n=6$. 


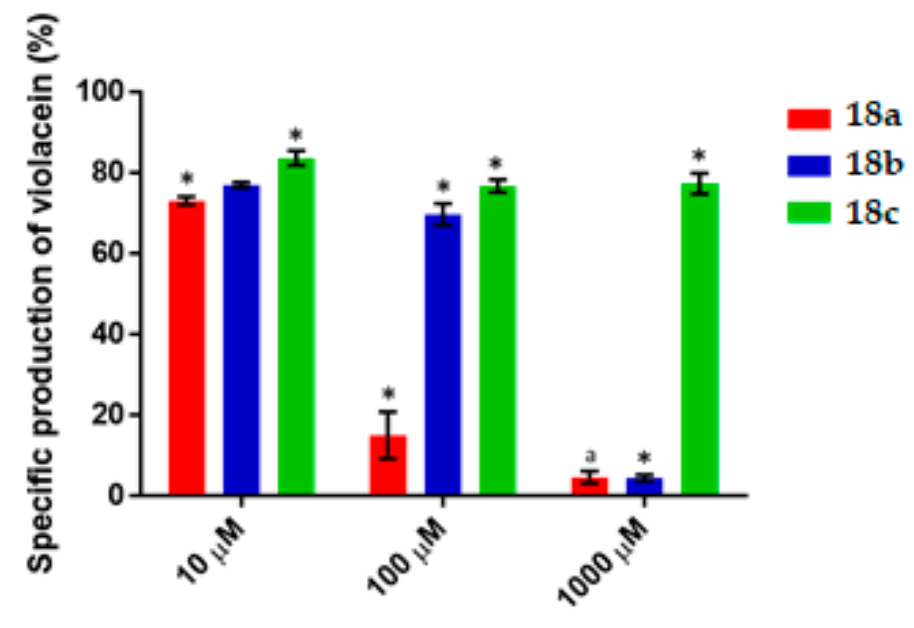

Concentration<smiles>CC(C)(C)SCC(=O)Nc1cccc(Cl)c1</smiles><smiles>O=C(CSc1nc2ccc(Cl)cc2[nH]1)NCc1ccc(Cl)cc1</smiles>

$18 b$<smiles>CCCCCCCCCSc1nc2ccc(Cl)cc2[nH]1</smiles>

$18 \mathrm{c}$

Figure 6. Violacein specific production by Chromobacterium violaceum CV026 in the presence of the synthesized benzimidazoles at 10,100 and $1000 \mu \mathrm{M}$ concentrations. Data are presented as percentages of violacein specific production (mean \pm SEM) and normalized on the violacein production without compound addition and this was considered as $100 \%$. Significance was confirmed by the Student's $t$-test with an accuracy of ${ }^{*} p<0.05$ at the labelled bars; ${ }^{a}$ Indicates an antimicrobial effect of the compound. Experiments were performed with $n=6$.

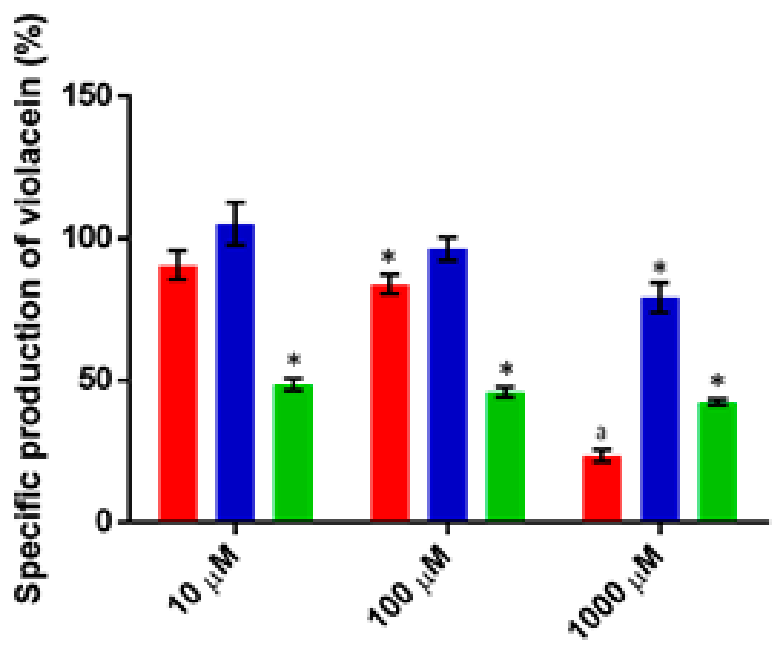

Concentration
$19 \mathrm{a}$

- $19 \mathrm{~b}$

$19 \mathrm{c}$<smiles>CCCC(=O)Nc1ccc(Cl)cn1</smiles><smiles>CCCCCC(=O)Nc1ccc(Cl)cn1</smiles>

$19 \mathrm{~b}$<smiles>CCCCCCCCC(=O)Nc1ccc(Cl)cn1</smiles>

$19 \mathrm{c}$

Figure 7. The specific production of violacein by Chromobacterium violaceum CV026 in the presence of the synthesized compounds $(\mathbf{1 9 a}-\mathbf{c})$ at 10,100 and $1000 \mu \mathrm{M}$. Data are expressed as a percentage of specific production of violacein (mean \pm SEM), normalized on the violacein production without compound addition and this considered as $100 \%$. Significance was confirmed by the Student's $t$-test with an accuracy of ${ }^{*} p<0.05$ at the marked bars. ${ }^{a}$ Indicates an antimicrobial effect of the tested compound. Experiments were performed with $n=6$. 


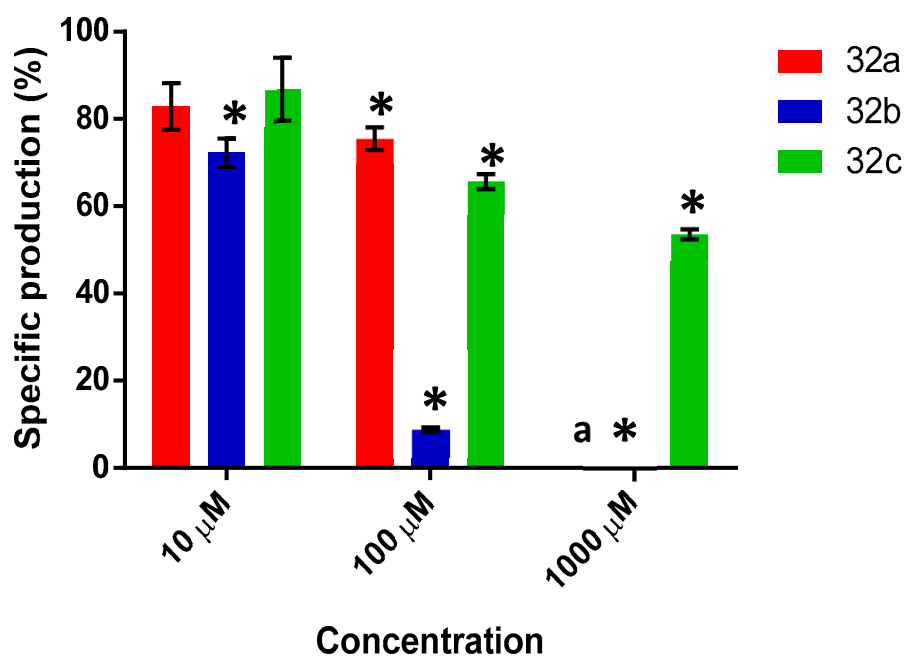<smiles>O=C(COc1ccc(C2=NCCN2)cc1)Nc1cccc(Cl)c1</smiles><smiles>O=C(COc1ccc(C2=NCCN2)cc1)NCc1ccc(Cl)cc1</smiles>

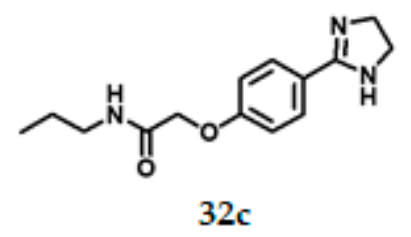

Figure 8. The specific production of violacein by Chromobacterium violaceum CV026 in the presence of the synthesized imidazolines (32a-c) at 10,100 and $1000 \mu \mathrm{M}$ concentrations. Data are presented as percentages of violacein specific production (mean \pm SEM), and normalized on the violacein production without compound addition and this was considered as $100 \%$. Significance was confirmed by the Student's $t$-test with an accuracy of ${ }^{*} p<0.05$ at the marked bars. ${ }^{a}$ Denotes antimicrobial effect of the tested compound. Experiments were performed with $n=6$.

\subsection{Thiazoles}

The QS inhibitory activity of the series of thiazoles is illustrated in Figure 4. No such effect was found for 16a at any concentration. Thiazole $\mathbf{1 6 b}$ at 10, 100 and $1000 \mu \mathrm{M}$ showed low-moderate QS inhibitory activity (32\%, 39\% and 51\%, respectively) with an $\mathrm{IC}_{50}=925.0 \mu \mathrm{M}$. The thiazole $16 \mathrm{c}$ was QSI only at $10 \mu \mathrm{M}$, causing limited inhibition (22\%).

\subsection{Thiazolines}

The results for thiazoline series are shown in Figure 5. Thiazoline 17a displayed a moderate QS inhibition at 10 and $100 \mu \mathrm{M}$ being of $44 \%$ and $47 \%$ respectively, while at $1000 \mu \mathrm{M}$ it behaved as antimicrobial. Thiazoline $\mathbf{1 7 b}$ exhibited a limited to good inhibition at 10,100 and $1000 \mu \mathrm{M}$ being of $23 \%, 37 \%$ and $65 \%$ respectively, in addition $17 \mathrm{~b}$ gave an $\mathrm{IC}_{50}$ value of $517.86 \mu \mathrm{M}$. Compound $17 \mathrm{c}$ reduced violacein production $23 \%, 24 \%$ and $48 \%$ at 10,100 and $1000 \mu \mathrm{M}$ respectively.

\subsection{Benzimidazoles}

For the benzimidazole series (Figure 6), 18a gave $27 \%$ and $85 \%$ QS inhibition at 10 and $100 \mu \mathrm{M}$ respectively, presented a value of $\mathrm{IC}_{50}$ of $36.67 \mu \mathrm{M}$, and behaved as an antimicrobial at $1000 \mu \mathrm{M}$. For $\mathbf{1 8 b}$ at 100 and $1000 \mu \mathrm{M}$, good and excellent activity as a QSI was found (31\% and $95 \%$, respectively). The $\mathrm{IC}_{50}$ value of $\mathbf{1 8 b}$ is $376.92 \mu \mathrm{M}$. For $\mathbf{1 8 c}$ the inhibitory effect was $17 \%, 24 \%$ and $23 \%$ at 10,100 and $1000 \mu \mathrm{M}$, respectively.

Activity as QSI of benzimidazole 18 a (85\% QS inhibition at $100 \mu \mathrm{M}, \mathrm{IC}_{50}$ of $\left.36.67 \mu \mathrm{M}\right)$ is comparable than 2-[4-(hexyloxy)phenyl]-4,5-dihidro- $1 H$-imidazole $(65 \%$ QS inhibition at $90 \mu \mathrm{M}$, $\mathrm{IC}_{50}=56.38 \mu \mathrm{M}$ ) [21], more active than 4-nitro-pyridine- $N$-oxide (active at $100 \mu \mathrm{M}$ ), the best synthetic quorum sensing inhibitor (QSI) in a screening of 27 synthetic compounds and 27 natural extracts [11,45]. However benzimidazole 18a is not QSI like 2-(4'-chlorophenoxy)- $N$-butanoyl homoserine lactone $\left(\mathrm{IC}_{50}=377 \mathrm{nM}\right)[7]$. 


\subsection{Pyridines}

Pyridine 19a exhibited QS inhibition activity (17\%) at $100 \mu \mathrm{M}$, while at $1000 \mu \mathrm{M}$ it behaved as an antimicrobial. Compound $19 \mathrm{~b}$ was active against QS only at $1000 \mu \mathrm{M}$, eliciting a $21 \%$ inhibition. In the case of 19c, all three concentrations $(10,100$ and $1000 \mu \mathrm{M})$ showed an QS inhibitory effect (52\%, 55\% and 58\%, respectively). (Figure 7). According to the experimental data, the $\mathrm{IC}_{50}$ was calculated to be $9.66 \mu \mathrm{M}$. Pyridine 19c is the best compound of all those tested in this work, its activity as QSI is comparable to 2 and 3 ( $\mathrm{IC}_{50}=1.1 \mu \mathrm{M}$ and $2.2 \mu \mathrm{M}$ respectively) [7]. It is more active than other synthesized inhibitors like 4-nitro-pyridine- $N$-oxide (active at $100 \mu \mathrm{M}$ ) [11,45] or 2-[4'-(pentyloxy)phenyl]-4,5-dihydro- $1 H$-imidazole $\left(\mathrm{IC}_{50}=56.38 \mu \mathrm{M}\right)$ but is not better than 4-[(4'-chorophenoxy)- $N$-(2-oxotetrahydrofuran-3-yl)]butanamide $\left(\mathrm{IC}_{50}=377 \mathrm{nM}\right)$ [7] nor better than $N$-[4'-(4,5-dihydro-1H-imidazol-2-yl)phenyl]nonamide (activity as QSI from $1 \mathrm{nM}$ ) [24].

\subsection{Imidazolines}

For the series of imidazolines (Figure 8), 32a and 32c at $100 \mu \mathrm{M}$ exhibited $24 \%$ and $34 \%$ activity as QSI, respectively. Imidazoline 32b was QSI at all concentrations and displayed $\mathrm{IC}_{50}=65.09 \mu \mathrm{M}$. The QS inhibition activity of $\mathbf{3 2 b}$ is comparable to other synthesized bioisosteres [21]. Imidazoline $\mathbf{3 2} \mathbf{c}$ at $1000 \mu \mathrm{M}$ afforded $46 \%$ activity and compound 32a behaved as an antimicrobial at the latter concentration. Compound $\mathbf{3 2} \mathbf{b}$ is one of the top three in the series of compounds synthesized in this work, its QS inhibition activity is lower than that of ethyl (4-fluorobenzoyl) acetate $\left(\mathrm{IC}_{50}=23 \mu \mathrm{M}\right)$ the best QSI of a library with 26 compounds [46], but it is similar to 2-[4'-(pentyloxy)phenyl]-4,5-dihydro- $1 H$-imidazole $\left(\mathrm{IC}_{50}=56.38 \mu \mathrm{M}\right)$ and more active than QSI 4-nitro-pyridine- $N$-oxide (active at $\left.100 \mu \mathrm{M}\right)[11,45]$.

\section{Docking Results}

Molecular docking was carried out to provide insight into the non-bonding interactions of the test compounds with the CviR protein (PDB code: 3QP6). The binding modes were observed and the affinity energy of each compound was calculated and expressed as $\Delta \mathrm{G}(\mathrm{kcal} / \mathrm{mol})$. The Docking simulations were performed with AutoDock 4.2, utilizing the blind docking method. The grid box size was adjusted to $126 \AA^{3}$ with a grid spacing of $0.375 \AA^{3}$. The Lamarckian genetic algorithm was employed with a randomized initial population of 100 individuals and a maximum number of energy evaluations of $1 \times 10^{7}$. [47] The docking results were analyzed and visualized on AutoDockTools and PyMOL [48], represented as 3D plot conformations. The affinity energies of the evaluated compounds are shown in Table 7.

Molecular Docking of compounds 32a-c were performed by us in a previous study [44] obtaining the following results: $32 \mathrm{a}, \Delta \mathrm{G},=-11.39 \mathrm{kcal} / \mathrm{mol} ; 32 \mathrm{~b}, \Delta \mathrm{G}=-8.52 \mathrm{kcal} / \mathrm{mol}$ y $32 \mathrm{c}, \Delta \mathrm{G}=-10.42$ and AHL (1), $\Delta \mathrm{G}=-7.26 \mathrm{kcal} / \mathrm{mol}$.

The theoretical calculations reveal that all tested compounds had greater affinity for the protein than the native ligand $\mathrm{C} 6$-AHL $\left(1, \mathrm{R}_{1}=\mathrm{H}, \mathrm{R}^{2}=\mathrm{C}_{3} \mathrm{H}_{7}\right)$. In addition, a strong correlation exists between the in silico and experimental results. For example, $17 \mathbf{b}-\mathbf{c}, \mathbf{1 8 a}-\mathbf{c}$ and $19 \mathrm{c}$ displayed good experimental inhibition and had the greatest affinity energies in silico.

The amino acids residues of the protein involved in the interaction with the C6-AHL, the native ligand, also participate in the binding of the most test compounds. There are hydrogen bond interactions of the polar groups of the compounds with the TRP84, ASP97 and SER155 residues. Additionally, there are $\pi-\pi$ interactions of the phenyl ring on the thiazolines $17 \mathbf{a}$ and $17 \mathbf{b}$ with the phenyl group of TYR88, of the benzimidazoles 18a-b with TYR80, and of the pyridine ring of compound 19c with TRP111. Morever, hydrophobic interactions took place with most of the residues at the binding site, including ILE57, VAL59, MET72, LEU85, ILE99, PHE126, ALA130 and MET135. (Figure 9). 
Table 7. Affinity energies $(\Delta G)$ and amino acid residues of the binding site for the ligands evaluated.

\begin{tabular}{|c|c|c|}
\hline Ligand & $\Delta \mathrm{G}(\mathrm{kcal} / \mathrm{mol})$ & Amino Acid Residues of the Binding Site \\
\hline 16a & -7.13 & ILE57, VAL59, TYR80, TRP84 *, LEU85, TYR88, ASP97 *, ILE99, TRP111, PHE115, PHE126, MET135, SER155 \\
\hline $16 b$ & -7.5 & VAL59, MET72, TYR80 *, TRP84, LEU85, TYR88, ASP97 *, ILE99, TRP111, PHE115, PHE126, ALA130, MET135, ILE153, SER155 * \\
\hline $16 \mathrm{c}$ & -7.19 & MET72, TYR80 *, TRP84, LEU85, TYR88, SER89, MET100, ILE153, SER155 * \\
\hline $17 \mathbf{a}$ & -7.7 & VAL75, TYR80 *, LEU85, TYR88 ^, ASP97 *, ILE99, TRP111, SER155 * \\
\hline $17 \mathrm{~b}$ & -8.51 & MET72, VAL75, TYR80, TRP84, LEU85, TYR88 ^ , ASP97 *, ILE99, TRP111, PHE126, SER155 * \\
\hline $17 \mathrm{c}$ & -8.77 & MET72, VAL75, TYR80, TRP84, LEU85, TYR88, ASP97, ILE99, TRP111, PHE115, PHE126, ALA130, MET135, ILE153, SER155 \\
\hline 18a & -9.58 & ILE57, VAL59, MET72, TYR80 ^ TRP84, LEU85, TYR88, SER89, ILE99, TRP111, PHE126, ALA130, MET135, ILE153, SER155 * \\
\hline $18 b$ & -9.51 & ILE57, VAL59, MET72, VAL75, TYR80 ^, TRP84, LEU85, TYR88, SER89, ILE99, TRP111, PHE126, ALA130, MET135, SER155* \\
\hline $18 \mathrm{c}$ & -8.52 & ILE57, VAL59, TYR80, LEU85, TYR88, SER89, ALA94, ILE99, TRP111, PHE126, ALA130, MET135, SER155 \\
\hline 19a & -7.15 & ILE57, VAL59, TYR80, TRP84 *, TYR88, ASP97 *, PHE115, PHE126, ALA130, MET135 \\
\hline 19b & -7.96 & TYR80, TRP84, TYR88 *, ASP97 *, ILE99, TRP111, PHE115, PHE126, MET135, SER155 * \\
\hline 19c & -8.09 & ILE57, VAL59, MET72, TYR80, TRP84 *, LEU85, TYR88, ASP97, ILE99, TRP111 ` , PHE115, PHE126, ALA130, MET135, SER155 * \\
\hline $1\left(\mathrm{R}_{1}=\mathrm{H}, \mathrm{R}_{2}=\mathrm{C}_{3} \mathrm{H}_{7}\right)$ & -6.63 & ILE57, TYR80, TRP84 * LEU85, TYR88, ASP97 *, TRP111, PHE126, SER155 \\
\hline
\end{tabular}

Hydrogen bond interaction $(*), \pi-\pi$ interaction ( $(\boldsymbol{)})$. 

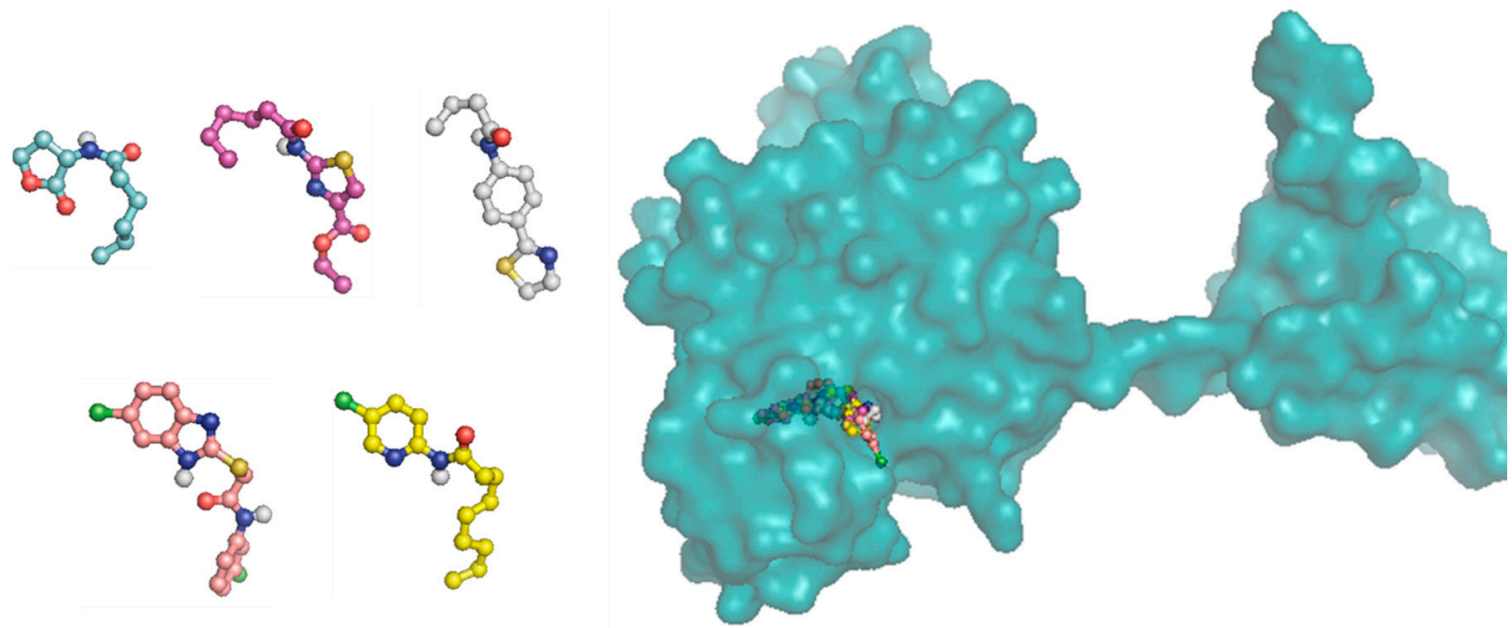

Figure 9. 3 D plot conformation of molecular docking of ligands C6-AHL, 16b, 17a, 18a and 19c in the active site of the CviR protein.

The non-covalent interactions of the most active ligands evaluated $(\mathbf{1 7 b}, \mathbf{1 8 a}$ and $19 \mathbf{c})$ are observed in the Figures 10-12. The $\pi-\pi$ interactions in the protein-compound complexes highlight the relevance of the phenyl moiety in the chemical structure of the test compounds. Other non-covalent interactions are involved in these complexes, such as hydrophobic and hydrogen bond interactions.

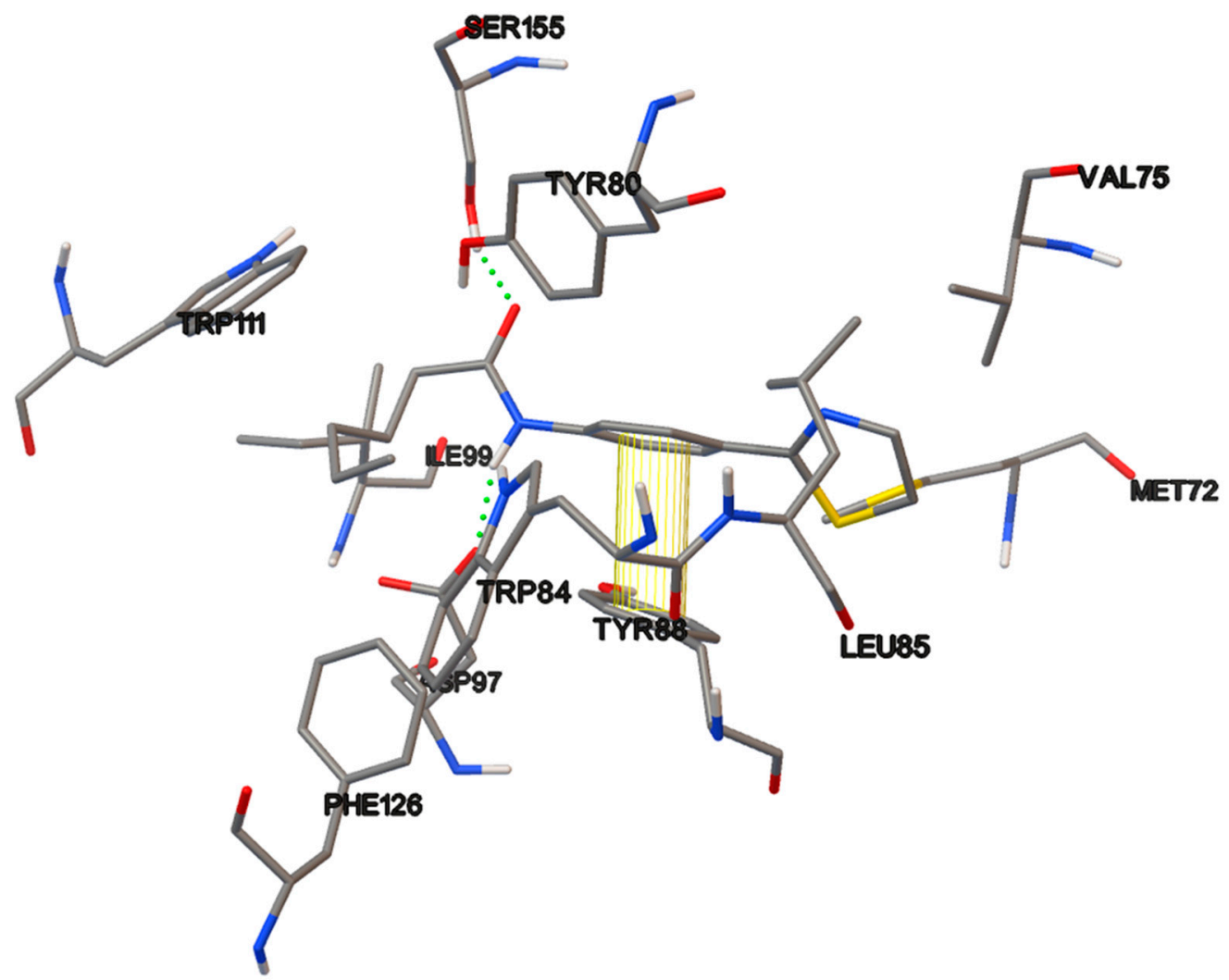

Figure 10. 3 D plot conformation of non-covalent interactions in the ligand-protein complex containing compound $\mathbf{1 7 b}$. 


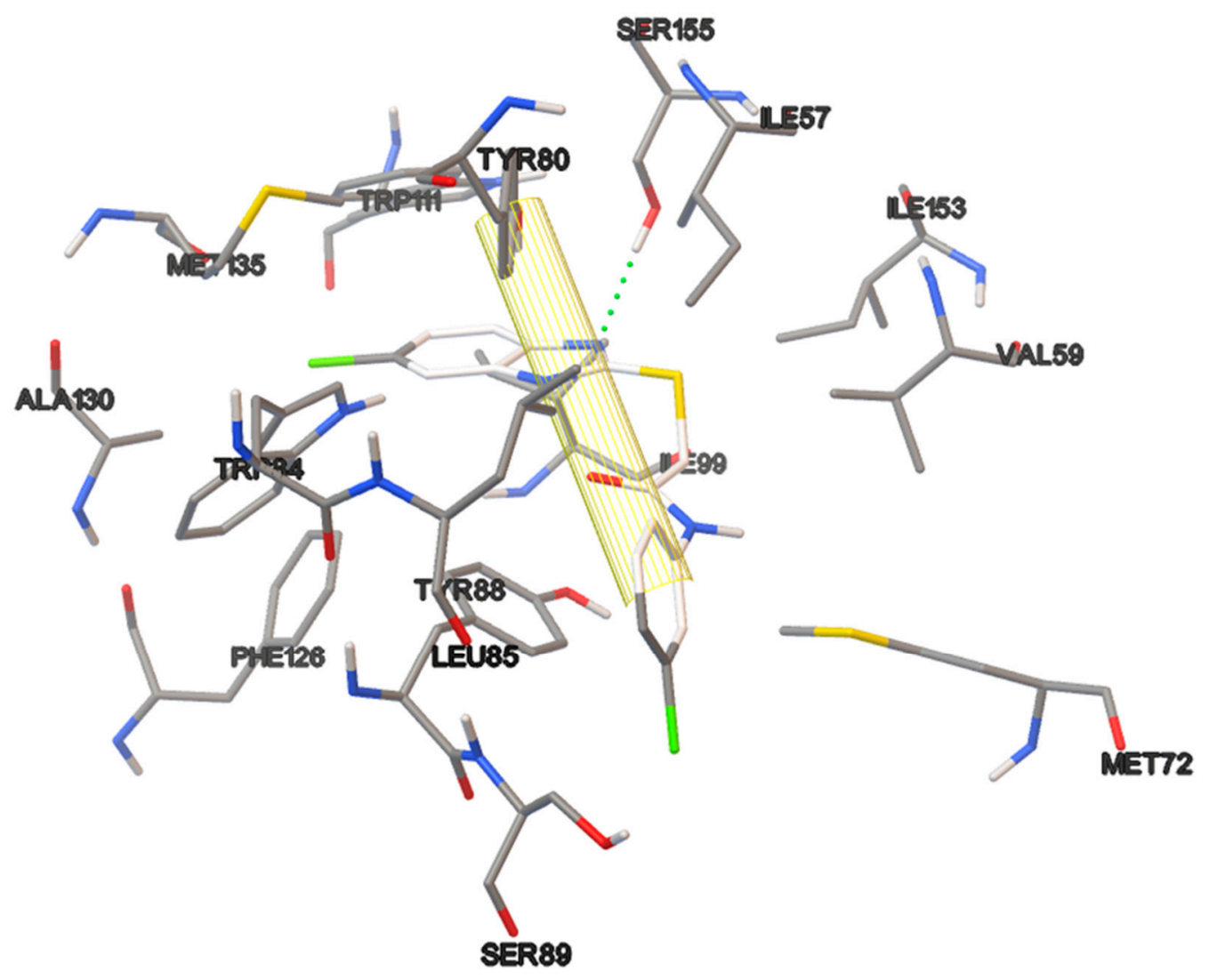

Figure 11. Non-covalent interactions of the ligand-protein complex containing 18a.

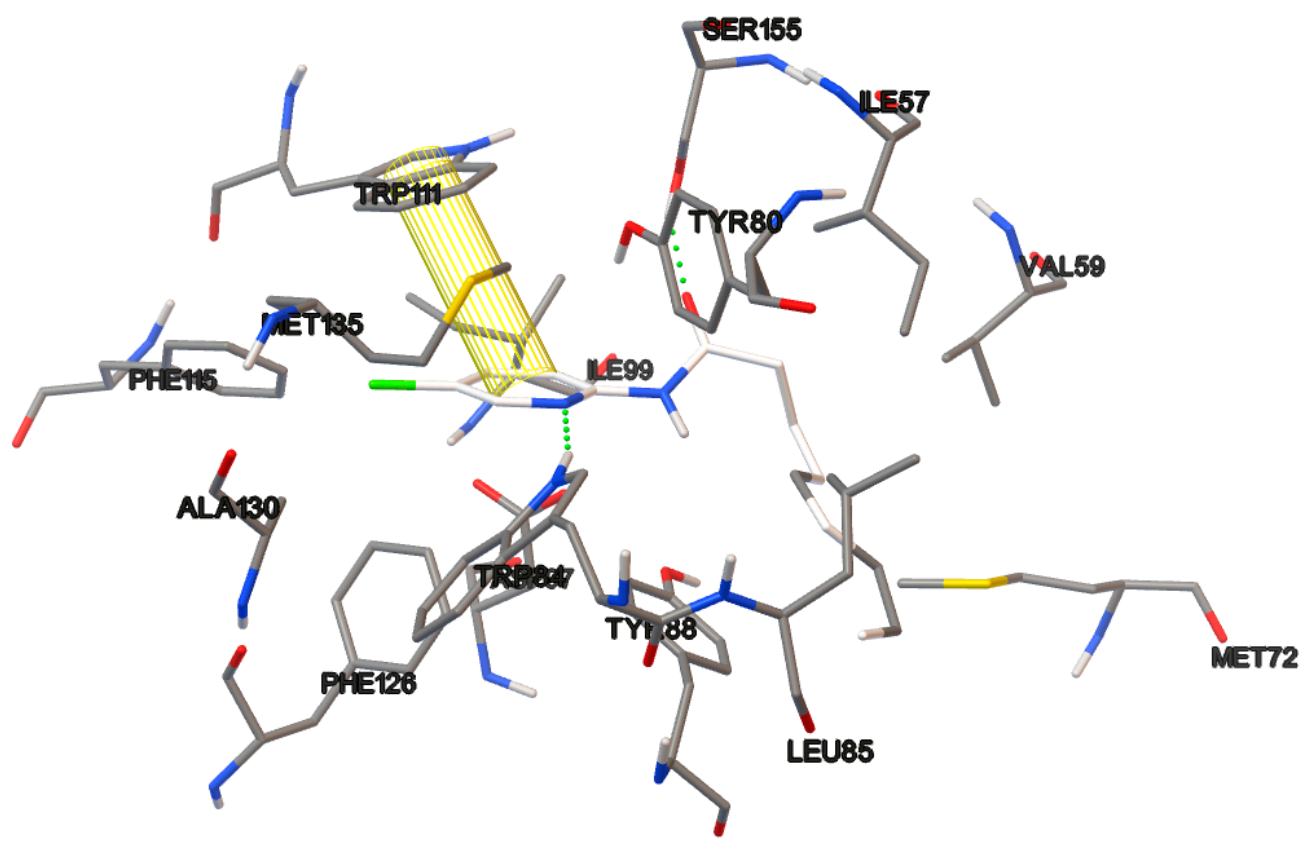

Figure 12. Non-covalent interactions of the ligand-protein complex containing compound 19c.

\section{Structure-Activity Relationship}

The elements present in the bioisosteres of this work were a heterocycle, the amide group and the side chain. In one of the 5 bioisosteres, a phenyl ring was introduced as a linker between the amide and the heterocycle (17). 
The chain length is important for the activity, not because of the interactions that it establishes, since they are all hydrophobic, but rather because of the size that permits other interactions; thus the compound 16a that has an aromatic ring, the thiazol, and the amide group but a chain of only 3C, did not display activity at any concentration. According to the Docking analysis this compound does not satisfy the size required to give all interactions like its homologous $\mathbf{1 6 b}$ and $\mathbf{1 6 c}$. The latter compounds showed hydrogen bonding between the $\mathrm{C}=\mathrm{O}$ of the amido group and TYR 80 and SER 155 .

Thiazolines 17 contain a thiazoline ring, a phenyl as a connector, the amido group, and propyl, pentyl and heptyl chains. They exhibited some degree of QS inhibition, except for 17a at $1000 \mu \mathrm{M}$, showing antimicrobial activity. In an earlier work, our group synthesized thiazolines, 33a-c, (Figure 13) like the thiazolines $\mathbf{1 7}$ but without the phenyl conector; all those thiazolines were inactive as QSI [29,49]. Thiazoline $\mathbf{1 7 b}$ afforded a low activity as QSI, $23 \%$ and $37 \%$ at 10 and $100 \mu \mathrm{M}$, respectively, as well as $65 \%$ at $1000 \mu \mathrm{M}$. The phenyl linker enables a greater number of interactions than the aliphatic chains alone, and increases the length of the compound. The $\pi-\pi$ interactions of the complex formed by compound $\mathbf{1 7 b}$ and tyrosine 88 at the active site the CviR protein is illustrated in Figure 12.

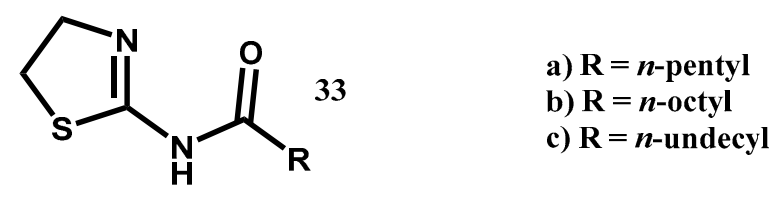

Figure 13. Inactive thiazolines as QSI.

All benzimidazoles (18) with a thiol functionality display good QSI activity, 18a and 18b, so the compound 18a exhibited $85 \%$ QSI at $100 \mu \mathrm{M}$ and $\mathbf{1 8 b} 95 \%$ at $1000 \mu \mathrm{M}$. Benzimidazol 18c displayed only 17, 24 and $23 \%$ inhibitory activity at 10, 100 and $1000 \mu \mathrm{M}$, respectively. According to the Docking simulations, the benzimidazole ring occupies the space of the lactone and the amide of AHL, while thioacetamide engages the space of the aliphatic chain of AHL. The interactions of the protein with the benzimidazole rings were similar to those found with the lactone ring and the amido group of AHL Moreover, the phenyl ring of $\mathbf{1 8} \mathbf{a}$ y $\mathbf{1 8 b}$ presents $\pi-\pi$ interactions with the receptor. Conversely, no $\pi-\pi$ interactions were observed for $18 \mathrm{c}$ because there is no phenyl ring in its structure, and the benzimidazol ring, which could give these interactions, establishes the interactions mentioned above. Benzimidazoles 18a-b do not contain an aliphatic chain; but have a thioacetamide group, giving them greater length and flexibility.

Since 18a is QSI at $100 \mu \mathrm{M}$ and antimicrobial at $1000 \mu \mathrm{M}$, it is possible to find a concentration that is able to restore sensitivity to an antibiotic. It is known that the QSI addition to an antibiotic can restore the sensitivity to the drug and increase its potency $[11,50]$, therefore we consider that benzimidazol 18a that behaves as very good QSI at one concentration and antimicrobial at another is very promising.

Pyridine 19a with a propyl chain exhibited little QSI activity, $17 \%$ at $100 \mu \mathrm{M}$ and behaved as an antimicrobial at $1000 \mu \mathrm{M}$ suggesting that chain was too short to properly couple to the protein. Among the pyridines, the best activity as a QSI was produced by 19c, the compound with a nonyl chain. Its inhibitory activity was surprisingly similar at all three concentrations $(52,55$ and $58 \%$ at 10,100 and $1000 \mu \mathrm{M}$, respectively), which has no apparent explanation. Pyridines $19 \mathbf{a}$ and $\mathbf{1 9 b}$ generate the same hydrogen bond as AHL between NH and Asp 97. With 19b, there is in an additional hydrogen bond of $\mathrm{C}=\mathrm{O}$ of the amide group with SER 155 and TYR 80. It was observed that 19c is rotated $180^{\circ}$ in relation to AHL and forms two hydrogen bonds: one between the compound 19c carbonyl and SER 155 , and the other between N and TRP 84 . All imidazolines displayed activity as QSI at $100 \mu \mathrm{M}$ and $1000 \mu \mathrm{M}$, although only $\mathbf{3 2 b}$ (at $1000 \mu \mathrm{M}$ ) showed good activity. Compound 32c, containing a propyl lateral chain, gave rise to 34 and $46 \%$ QSI at 100 and $1000 \mu \mathrm{M}$ respectively. 


\section{Materials and Methods}

\subsection{General}

All reagents and solvents were purchased from Sigma Aldrich (Toluca, Mexico) and used without further purification. Reactions were monitored by thin-layer chromatography (TLC) on Merck F253 silica gel aluminum sheets, and spots were revealed with ultraviolet (UV) light (254 nm). NMR experiments were carried out in Varian NMR System (500 MHz and $125 \mathrm{MHz}$ ), Varian Mercury (300 MHz and $75 \mathrm{MHz}$ ) and Bruker ASCEND (600 MHz and $150 \mathrm{MHz}) .{ }^{1} \mathrm{H}$ NMR and ${ }^{13} \mathrm{C}$ spectra were assigned with the help of 2-D experiments (gHSQC and gHMBC). The chemical shifts $(\delta)$ are given in ppm. Mass spectra (MS) were recorded on a Bruker Amazon Speed (ESI). Infrared (IR) spectra were obtained on a Perkin Elmer FT-IR Spectrum 2000 spectrometer from the ENCB-IPN spectroscopy instrumentation center. Melting points were determined on an Electrothermal MEL-TEMP apparatus and are uncorrected. Microwave reactions were accomplished on a CEM Discovery SP apparatus.

\subsection{Procedure for the Synthesis of Ethyl 2-Aminothiazol-4-carboxylate, 22}

Ethyl bromine pyruvate (7.69 mmol, $1 \mathrm{eq})$, thiourea $(7.69 \mathrm{mmol}, 1 \mathrm{eq})$ and $15 \mathrm{~mL}$ of EtOH were added to a flask equipped with a magnetic stirring bar and left to reaction mixture at rt for $16 \mathrm{~h}$. At the end of this period, the solvent was evaporated under reduced pressure, followed by the addition of $40 \mathrm{~mL}$ of $20 \%$ aqueous potassium carbonate to the residue. The suspension formed was maintained under constant stirring for $30 \mathrm{~min}$ before subjecting it to vacuum filtration. The solid retained on the filter paper was washed with $40 \mathrm{~mL}$ of distilled water in two $20 \mathrm{~mL}$ portions and oven-dried at $40{ }^{\circ} \mathrm{C}$.

Ethyl 2-Aminothiazol-4-Carboxylate, 22

Yield: 85\%. White solid. ${ }^{1} \mathrm{H}$ NMR (300 MHz, DMSO- $\left.d_{6}\right) \delta: 7.44(\mathrm{~s}, 1 \mathrm{H}, \mathrm{H}-5), 7.24(\mathrm{~s}, 2 \mathrm{H}, \mathrm{NH})$, $4.17(\mathrm{q}, J=7.10 \mathrm{~Hz}, 2 \mathrm{H}, \mathrm{H}-8), 1.22(\mathrm{t}, J=7.10 \mathrm{~Hz}, 3 \mathrm{H}, \mathrm{H}-9) .{ }^{13} \mathrm{C}$ NMR $\left(75 \mathrm{MHz}, \mathrm{DMSO}-d_{6}\right) \delta 168.6(\mathrm{C}-2)$, 161.5 (C-6), 142.6 (C-4), 117.4 (C-5), 60.6 (C-8), 14.6 (C-9). DIP-MS (ESI; M + Na) m/z (calculated): 195.01, $m / z$ (measured): 195.00 .

\subsection{Synthesis of Ethyl 2-Acylamidothiazol-4-carboxylate, $\mathbf{1 6}$}

2-Amino thiazole $\left(1.74 \mathrm{mmol}, 1 \mathrm{eq}\right.$ ) and $2 \mathrm{~mL}$ of carboxylic acid (butanoic acid at $150{ }^{\circ} \mathrm{C}$, hexanoic acid at $150{ }^{\circ} \mathrm{C}$, octanoic acid at $180{ }^{\circ} \mathrm{C}$ ) were added to a reaction vial equipped with magnetic stirring, the reaction mixture was warmed for $90 \mathrm{~min}$. It was then transferred to an aqueous solution of $20 \%$ potassium carbonate $(40 \mathrm{~mL})$ and allowed the mixture to stir for $30 \mathrm{~min}$. Subsequently, the suspension was vacuum filtered and the solid obtained washed with distilled water $(2 \times 20 \mathrm{~mL})$ and oven-dried at $40{ }^{\circ} \mathrm{C}$.

\section{Ethyl 2-Butyramidothiazol-4-Carboxylate, 16a}

Yield: $82 \%$. Brownish solid; m.p. $145-148{ }^{\circ} \mathrm{C}$. Lit. [30] $150-151{ }^{\circ} \mathrm{C} R_{\mathrm{f}}=0.6$ (AcOEt). IR $\left(\mathrm{CH}_{2} \mathrm{Cl}_{2}\right)$ $\bar{v}=3256.8,1720.1,1690.4,1546.0,1215.1 \mathrm{~cm}^{-1} .{ }^{1} \mathrm{H} \mathrm{NMR}\left(300 \mathrm{MHz}, \mathrm{CDCl}_{3}\right) \delta: 7.81\left(\mathrm{~s}, 1 \mathrm{H}, \mathrm{H}-5^{\prime}\right)$, 4.35 (q, $\left.J=7.12 \mathrm{~Hz}, 2 \mathrm{H}, \mathrm{H}-3^{\prime \prime}\right), 2.43(\mathrm{t}, J=7.47 \mathrm{~Hz}, 2 \mathrm{H}, \mathrm{H}-2), 1.70$ (m, 2H, H-3), 1.35 (t, J= 7.12 Hz, $\left.3 \mathrm{H}, \mathrm{H}-4^{\prime \prime}\right), 0.94(\mathrm{t}, J=7.47 \mathrm{~Hz}, 3 \mathrm{H}, \mathrm{H}-4) .{ }^{13} \mathrm{C} \mathrm{NMR}\left(75 \mathrm{MHz}, \mathrm{CDCl}_{3}\right) \delta 171.9(\mathrm{C}-1), 161.4\left(\mathrm{C}-1^{\prime \prime}\right)$, $159.0\left(\mathrm{C}-2^{\prime}\right), 141.1\left(\mathrm{C}-4^{\prime}\right), 122.2\left(\mathrm{C}-5^{\prime}\right), 61.4\left(\mathrm{C}-3^{\prime \prime}\right), 37.9$ (C-2), 18.3 (C-3), 14.3 (C-4' $), 13.6$ (C-4). DIP-MS (ESI; $\left.\mathrm{M}+\mathrm{Na}^{+}\right) \mathrm{m} / z$ (calculated): 265.06, $m / z$ (measured): 265.10.

\section{Ethyl 2-Hexanamidothiazol-4-Carboxylate, $\mathbf{1 6 b}$}

Yield: $85 \%$. Brownish solid; m.p. $129-132{ }^{\circ} \mathrm{C}$. Lit. [30] $135-136{ }^{\circ} \mathrm{C} R_{\mathrm{f}}=0.66$ (AcOEt). IR $\left(\mathrm{CH}_{2} \mathrm{Cl}_{2}\right)$ $\bar{v}=3256.8,1723.4,1680.7,1547.6,1211.1 \mathrm{~cm}^{-1} .{ }^{1} \mathrm{H} \mathrm{NMR}\left(300 \mathrm{MHz}, \mathrm{CDCl}_{3}\right) \delta: 7.82\left(\mathrm{~s}, 1 \mathrm{H}, \mathrm{H}-5^{\prime}\right)$, $4.35\left(\mathrm{q}, J=7.13 \mathrm{~Hz}, 2 \mathrm{H}, \mathrm{H}-3^{\prime \prime}\right), 2.44(\mathrm{t}, J=7.59 \mathrm{~Hz}, 2 \mathrm{H}, \mathrm{H}-2), 1.68(\mathrm{~m}, 2 \mathrm{H}, \mathrm{H}-3), 1.36(\mathrm{t}, J=7.13 \mathrm{~Hz}, 3 \mathrm{H}$, $\left.\mathrm{H}-4^{\prime \prime}\right), 1.28$ (m, 4H, H-4,5), 0.86 (m, 3H, H-6). ${ }^{13} \mathrm{C} \mathrm{NMR} \mathrm{(75} \mathrm{MHz,} \mathrm{CDCl} 3$ ) $\delta 171.9(\mathrm{C}-1), 161.4\left(\mathrm{C}-1^{\prime \prime}\right)$, 
158.8 (C-2), 141.19 (C-4'), 122.18 (C-5'), 61.37 (C-3") 36.05 (C-2), 31.21 (C-4), 24.6 (C-3), 22.3 (C-5), 14.3 (C-4") 13.8 (C-6). DIP-MS (ESI; M + Na) m/z (calculated): 293.09, m/z (measured): 293.16.

Ethyl 2-Octanamidothiazol-4-Carboxylate, 16c

Yield: $80 \%$. Brownish solid; m.p. $102-104{ }^{\circ} \mathrm{C}$. Lit. [30] 109-111 ${ }^{\circ} \mathrm{C} . \mathrm{R}_{\mathrm{f}}=0.68$ (AcOEt). IR $\left(\mathrm{CH}_{2} \mathrm{Cl}_{2}\right)$ $\bar{v}=3245.9,1725.1,1689.5,1544.2,1214.2 \mathrm{~cm}^{-1} .{ }^{1} \mathrm{H}$ NMR $\left(300 \mathrm{MHz}, \mathrm{CDCl}_{3}\right) \delta: 10.63(\mathrm{~s}, 1 \mathrm{H}, \mathrm{NH})$, $7.82\left(\mathrm{~s}, 1 \mathrm{H}, \mathrm{H}-5^{\prime}\right), 4.35$ (q, J = 7.11 Hz, 2H, H-3"') $2.44(\mathrm{t}, J=4.54 \mathrm{~Hz}, 2 \mathrm{H}, \mathrm{H}-2), 1.65(\mathrm{~m}, 2 \mathrm{H}, \mathrm{H}-3)$, $1.36\left(\mathrm{t}, J=7.11 \mathrm{~Hz}, 3 \mathrm{H}, \mathrm{H}-4^{\prime \prime}\right), 1.24(\mathrm{~m}, 8 \mathrm{H}, \mathrm{H}-4,5,6,7), 0.84(\mathrm{t}, J=6.19 \mathrm{~Hz}, 3 \mathrm{H}, \mathrm{H}-8) .{ }^{13} \mathrm{C} \mathrm{NMR}(75 \mathrm{MHz}$, $\left.\mathrm{CDCl}_{3}\right) \delta 172.0(\mathrm{C}-1), 161.3\left(\mathrm{C}-1^{\prime \prime}\right), 158.9\left(\mathrm{C}-2^{\prime}\right), 141.1\left(\mathrm{C}-4^{\prime}\right), 122.2\left(\mathrm{C}-5^{\prime}\right), 61.4\left(\mathrm{C}-3^{\prime \prime}\right), 36.1(\mathrm{C}-2)$, 31.6 (C-6), 29.0 (C-5), 28.9 (C-4), 24.9 (C-3), 22.5 (C-7), 14.31 (C-4"), 14.0 (C-8). DIP-MS (ESI; M + Na) $\mathrm{m} / \mathrm{z}$ (calculated): $321.12 \mathrm{~m} / \mathrm{z}$ (measured): 321.22 .

\subsection{Procedure for the Synthesis of 4-(Thiazolin-2-yl)-aniline, 25}

4-aminobenzonitrile ( $4.23 \mathrm{mmol}, 1 \mathrm{eq})$, cysteamine hydrochloride ( $6.34 \mathrm{mmol}, 1.5 \mathrm{eq})$, potassium carbonate (21.16 mmol, $5 \mathrm{eq}$ ) and $5 \mathrm{~mL}$ of a EtOH/ $\mathrm{H}_{2} \mathrm{O}(1: 1)$ mixture were added to an ACE pressure tube equipped with a magnetic stirring bar. The reaction mixture was subjected to heating in a sand bath at $110^{\circ} \mathrm{C}$ for $16 \mathrm{~h}$. At the end of this period, it was transferred to a ball flask and the solvent was evaporated under reduced pressure. The residue was suspended in distilled water $(20 \mathrm{~mL})$ and liquid-liquid extractions were made with $\mathrm{CH}_{2} \mathrm{Cl}_{2}(3 \times 15 \mathrm{~mL})$, the combined organic phases were dried with anhydrous $\mathrm{Na}_{2} \mathrm{SO}_{4}$ and evaporated in a ball flask under reduced pressure. The residue was purified by chromatographic column, using silica gel as the stationary phase and an 8:2 hexane/AcOEt mixture as the mobile phase.

4-(Thiazolin-2-yl) Aniline, 25

Yield: $82 \%$. Pink solid. ${ }^{1} \mathrm{H}$ NMR $\left(300 \mathrm{MHz}, \mathrm{CDCl}_{3}\right) \delta: 7.64(\mathrm{~d}, J=8.57 \mathrm{~Hz}, 2 \mathrm{H}, \mathrm{H}-3)$, $6.63(\mathrm{~d}, J=8.57 \mathrm{~Hz}, 2 \mathrm{H}, \mathrm{H}-2), 4.38\left(\mathrm{t}, J=8.2 \mathrm{~Hz}, 2 \mathrm{H}, \mathrm{H}-4^{\prime}\right), 3.96(\mathrm{~s}, 2 \mathrm{H}, \mathrm{NH}), 3.34(\mathrm{t}, J=8.2 \mathrm{~Hz}$, 2H, H-5'). ${ }^{13} \mathrm{C}$ NMR $\left(75 \mathrm{MHz}, \mathrm{CDCl}_{3}\right) \delta 167.9$ (C-2'), 149.3 (C-1), 130.0 (C-3), 123.5 (C-4), 114.2 (C-2), 64.9 (C-4'), 33.5 (C-5'). DIP-MS (ESI; M + H) m/z (calculated): 179.06, $\mathrm{m} / \mathrm{z}$ (measured): 179.06.

\subsection{Synthesis of N-[4-(Thiazolin-2-yl)-phenyl]-carboxamides, $\mathbf{1 7}$}

4-(Thiazolin-2-yl)-Aniline (1.96 mmol, 1 eq) and $2.5 \mathrm{~mL}$ of carboxylic acid (butanoic, hexanoic, octanoic acids) were added to a reaction vial equipped with a magnetic stirring bar. The vial was closed and the reaction mixture warmed (butanoic acid at $150{ }^{\circ} \mathrm{C}$, hexanoic acid at $150{ }^{\circ} \mathrm{C}$, octanoic acid at $180^{\circ} \mathrm{C}$ ) for $90 \mathrm{~min}$. At the end of that period, the reaction mixture was transferred to an aqueous solution of $20 \%$ potassium carbonate $(40 \mathrm{~mL})$ and left to stand under constant stirring for $30 \mathrm{~min}$. The suspension was subjected to vacuum filtration and the solid retained on the filter paper was washed with $40 \mathrm{~mL}$ of distilled water in two $20 \mathrm{~mL}$ portions, then oven-dried at $40^{\circ} \mathrm{C}$.

N-(4-(Thiazolin-2-yl) Phenyl) Butiramide, 17a

Yield: $85 \%$. Yellow solid; m.p. $138-140{ }^{\circ} \mathrm{C} . R_{\mathrm{f}}=0.3$ (AcOEt). IR $\left(\mathrm{CH}_{2} \mathrm{Cl}_{2}\right) \bar{v}=3296.6,1667.6$, 1598.3, 1527.5, 845.5 $\mathrm{cm}^{-1}$. ${ }^{1} \mathrm{H}$ NMR $\left(300 \mathrm{MHz}, \mathrm{CDCl}_{3}\right) \delta: 7.80(\mathrm{~s}, 1 \mathrm{H}, \mathrm{NH}), 7.76(\mathrm{~d}, J=8.58 \mathrm{~Hz}$, $\left.2 \mathrm{H}, \mathrm{H}-3^{\prime}\right), 7.58\left(\mathrm{~d}, J=8.58 \mathrm{~Hz}, 2 \mathrm{H}, \mathrm{H}-2^{\prime}\right), 4.42\left(\mathrm{t}, J=8.28 \mathrm{~Hz}, 2 \mathrm{H}, \mathrm{H}-4^{\prime \prime}\right), 3.39(\mathrm{t}, J=8.28 \mathrm{~Hz}, 2 \mathrm{H}$, $\left.\mathrm{H}-5^{\prime \prime}\right), 2.32(\mathrm{t}, J=7.42 \mathrm{~Hz}, 2 \mathrm{H}, \mathrm{H}-2), 1.73(\mathrm{~m}, 2 \mathrm{H}, \mathrm{H}-3), 0.97(\mathrm{t}, J=7.35 \mathrm{~Hz}, 3 \mathrm{H}, \mathrm{H}-4) .{ }^{13} \mathrm{C} \mathrm{NMR}$ $\left(75 \mathrm{MHz}, \mathrm{CDCl}_{3}\right) \delta 171.8(\mathrm{C}-1), 168.0\left(\mathrm{C}-2^{\prime \prime}\right), 140.7\left(\mathrm{C}-1^{\prime}\right), 129.3\left(\mathrm{C}-3^{\prime}\right), 128.7\left(\mathrm{C}-4^{\prime}\right), 119.1\left(\mathrm{C}-2^{\prime}\right)$, $65.0\left(\mathrm{C}-4^{\prime \prime}\right), 39.6$ (C-2), 33.7 (C-5" ) 19.0 (C-3), 13.7 (C-4). DIP-MS (ESI; M+H) m/z (calculated): 249.10, $\mathrm{m} / z$ (measured): 249.15 .

N-(4-(Thiazolin-2-yl) Phenyl) Hexanamide, 17b

Yield: 88\%. Brownish solid; m.p. ${ }^{129-131}{ }^{\circ} \mathrm{C} . R_{\mathrm{f}}=0.46$ (AcOEt). IR $\left(\mathrm{CH}_{2} \mathrm{Cl}_{2}\right) \bar{v}=3301.0$, 1669.4, 1598.7, 1529.8, $843.9 \mathrm{~cm}^{-1}$. ${ }^{1} \mathrm{H}$ NMR $\left(300 \mathrm{MHz}, \mathrm{CDCl}_{3}\right) \delta: 7.76\left(\mathrm{~d}, J=8.59 \mathrm{~Hz}, 2 \mathrm{H}, \mathrm{H}-3^{\prime}\right)$, 
$7.65(\mathrm{~s}, 1 \mathrm{H}, \mathrm{NH}), 7.58\left(\mathrm{~d}, J=8.59 \mathrm{~Hz}, 2 \mathrm{H}, \mathrm{H}-2^{\prime}\right), 4.42\left(\mathrm{t}, J=8.3 \mathrm{~Hz}, 2 \mathrm{H}, \mathrm{H}-4^{\prime \prime}\right), 3.39(\mathrm{t}, J=8.3 \mathrm{~Hz}, 2 \mathrm{H}$, $\left.\mathrm{H}-5^{\prime \prime}\right), 2.34(\mathrm{t}, J=7.55 \mathrm{~Hz}, 2 \mathrm{H}, \mathrm{H}-2), 1.70(\mathrm{~m}, 2 \mathrm{H}, \mathrm{H}-3), 1.33(\mathrm{~m}, 4 \mathrm{H}, \mathrm{H}-4,5), 0.88(\mathrm{t}, J=6.44 \mathrm{~Hz}, 3 \mathrm{H}$, H-6). ${ }^{13} \mathrm{C}$ NMR (75 MHz, CDCl3) $\delta 171.7$ (C-1), 167.9 (C-2' $), 140.6\left(\mathrm{C}-1^{\prime}\right), 129.3\left(\mathrm{C}-3^{\prime}\right), 128.7$ (C-4'), 119.0 (C-2'), $65.0\left(\mathrm{C}-4^{\prime \prime}\right), 37.8$ (C-2), 33.677 (C-5") 31.4 (C-4), 25.2 (C-3), 22.4 (C-5), 13.9 (C-6). DIP-MS (ESI; M + Na) $m / z$ (calculated): 299.11, $m / z$ (measured): 299.20 .

N-(4-(Thiazolin-2-yl) Phenyl) Octanamide, 17c

Yield: $79 \%$. Brownish solid; m.p. $68-70{ }^{\circ} \mathrm{C} . R_{\mathrm{f}}=0.51$ (AcOEt). IR $\left(\mathrm{CH}_{2} \mathrm{Cl}_{2}\right) \bar{v}=3301.9,1667.5$, 1597.6, 1530.8, $844.1 \mathrm{~cm}^{-1} .{ }^{1} \mathrm{H}$ NMR (300 MHz, $\left.\mathrm{CDCl}_{3}\right)$ 8: $7.90(1 \mathrm{H}, \mathrm{NH}), 7.76\left(2 \mathrm{H}, \mathrm{H}-3^{\prime}\right), 7.59\left(2 \mathrm{H}, \mathrm{H}-2^{\prime}\right)$, $4.42\left(2 \mathrm{H}, \mathrm{H}-4^{\prime \prime}\right), 3.39$ (2H, H-5") 2.35 (2H, H-2), 1.69 (2H, H-3), 1.26 (8H, H-4,5,6,7), 0.86 (3H, H-8). ${ }^{13} \mathrm{C} \mathrm{NMR}(75 \mathrm{MHz}, \mathrm{CDCl} 3) \delta 171.7$ (C-1), 167.9 C-2" ) 140.7 (C-1'), 129.3 (C-3'), $118.9\left(\mathrm{C}-4^{\prime}\right), 64.9$ (C-4") , 33.7 (C-2), 31.6 (C-5"), 29.2 , 29.0 28.9, 25.5, 22.6, 14.1 (C-8). DIP-MS (ESI; M + H) m/z (calculated): 305.16, $\mathrm{m} / \mathrm{z}$ (measured): 305.27 .

\subsection{Procedure for the Synthesis of 5-Chloro-benzimidazole-2-thione, $\mathbf{2 7}$}

4-Chloro-phenylenediamine (5.61 mmol, $1 \mathrm{Eq})$, carbon disulfide $(7.23 \mathrm{mmol}, 1.3 \mathrm{Eq})$, potassium hydroxide (16.83 mmol, $3 \mathrm{eq}$ ) and $5 \mathrm{~mL}$ of an ethanol/water mixture (7:3) were placed in an ACE pressure tube charged with magnetic stirring. The reaction mixture was heated at $80^{\circ} \mathrm{C}$ for $5 \mathrm{~h}$, then the solvent was evaporated under reduced pressure and $15 \mathrm{~mL}$ of a $5 \%$ aqueous $\mathrm{HCl}$ solution were added to the residue. The suspension was left with stirring for $15 \mathrm{~min}$ and subsequently it was vacuum filtered, the solid obtained was washed with $2 \times 20 \mathrm{~mL}$ of distilled water, the solid was dried at $40^{\circ} \mathrm{C}$ in an oven.

5-chloro-1,3-dihydro-2H-Benzimidazol-2-Thione, 27

Yield: $88 \%$. Brownish solid. ${ }^{1} \mathrm{H}$ NMR $\left(300 \mathrm{MHz}\right.$, Acetone- $\left.d_{6}\right) \delta: 7.17(\mathrm{dd}, J=1.86,0.86 \mathrm{~Hz}, 1 \mathrm{H}$, H-6), $7.15(\mathrm{~d}, J=0.86 \mathrm{~Hz}, 1 \mathrm{H}, \mathrm{H}-4), 7.13(\mathrm{~d}, J=1.86 \mathrm{~Hz}, 1 \mathrm{H}, \mathrm{H}-7) .{ }^{13} \mathrm{C}$ NMR $\left(75 \mathrm{MHz}\right.$, Acetone- $\left.d_{6}\right) \delta$ 170.4 (C-2), 133.768 (C-4a), 131.7 (C-7a), 127.1 (C-5), 122.1 (C-6), 110.5 (C-7), 109.4 (C-4). DIP-MS (ESI; $\mathrm{M}-\mathrm{H}) \mathrm{m} / \mathrm{z}$ (calculated): 182.97, $\mathrm{m} / \mathrm{z}$ (measured): 182.88 .

\subsection{Alkylation of 5-Chloro-benzimidazole-2-thione, $\mathbf{1 8}$}

Benzimidazol-2-thione ( $1.35 \mathrm{mmol}, 1 \mathrm{eq})$, alkyl halide $(1.35 \mathrm{mmol}, 1 \mathrm{eq})$ and $15 \mathrm{~mL}$ of ethanol were placed in a $100 \mathrm{~mL}$ ball flask equipped with a magnetic stirring bar and the reaction mixture was left to stand for $16 \mathrm{~h}$ at $60^{\circ} \mathrm{C}$ before evaporating the solvent. The solid was suspended in an aqueous solution of $20 \%$ potassium carbonate $(30 \mathrm{~mL})$ and vacuum filtered. This solid was washed with $2 \times 20 \mathrm{~mL}$ of distilled water and oven-dried at $40{ }^{\circ} \mathrm{C}$.

2-[(6-chloro-1H-Benzoimidazol-2-yl) thio)-N-(3-Chlorophenyl)] Acetamide, 18a

Yield: $80 \%$. Purple solid; m.p. $228-231{ }^{\circ} \mathrm{C} . R_{\mathrm{f}}=0.28$ (hexane/AcOEt 7:3). IR $\left(\mathrm{CH}_{2} \mathrm{Cl}_{2}\right)$ $\bar{v}=1652.2,1586.4,1423.7 \mathrm{~cm}^{-1}$. ${ }^{1} \mathrm{H}$ NMR $\left(300 \mathrm{MHz}, \mathrm{DMSO}-d_{6}\right) \delta: 10.77(\mathrm{~s}, 1 \mathrm{H}, \mathrm{NH}), 7.77(\mathrm{~s}, 1 \mathrm{H}$, H-2'), $7.64\left(\mathrm{~d}, J=1.64 \mathrm{~Hz}, 1 \mathrm{H}, \mathrm{H}-7^{\prime \prime}\right), 7.57\left(\mathrm{~d}, J=8.63 \mathrm{~Hz}, 1 \mathrm{H}, \mathrm{H}-4^{\prime \prime}\right), 7.43\left(\mathrm{~d}, J=8.36 \mathrm{~Hz}, 1 \mathrm{H}, \mathrm{H}-6^{\prime}\right)$, $7.32\left(\mathrm{~m}, 2 \mathrm{H}, \mathrm{H}-5^{\prime}, 5^{\prime \prime}\right), 7.10\left(\mathrm{~d}, J=7.84 \mathrm{~Hz}, 1 \mathrm{H}, \mathrm{H}-4^{\prime}\right), 4.41(\mathrm{~s}, 2 \mathrm{H}, \mathrm{H}-2) .{ }^{13} \mathrm{C}$ NMR $\left(75 \mathrm{MHz}, \mathrm{DMSO}-d_{6}\right) \delta$ $166.1(\mathrm{C}-1), 152.3\left(\mathrm{C}-2^{\prime \prime}\right), 140.5\left(\mathrm{C}-1^{\prime}\right), 137.2\left(\mathrm{C}-7 \mathrm{a}^{\prime \prime}\right), 134.9$ (C-4a"), 133.5 (C-3'), $131.0\left(\mathrm{C}-5^{\prime}\right), 128.3\left(\mathrm{C}-6^{\prime}\right)$, 124.1 (C-5"), $123.8\left(\mathrm{C}-4^{\prime}\right), 119.0\left(\mathrm{C}-2^{\prime}\right), 118.0\left(\mathrm{C}-6^{\prime}\right), 115.1\left(\mathrm{C}-4^{\prime \prime}\right), 113.8$ (C-7"'), 36.9 (C-2). DIP-MS (ESI; M-H) $m / z$ (calculated): $349.99, \mathrm{~m} / \mathrm{z}$ (measured): 349.93 .

2-[(6-chloro-1H-Benzimidazol-2-yl) thio)- $N$-(4-chlorobenzyl] Acetamide, 18b

Yield: $83 \%$. Blue solid; m.p. $=115-118{ }^{\circ} \mathrm{C} . R_{\mathrm{f}}=0.15$ (hexane/AcOEt 7:3); IR $\left(\mathrm{CH}_{2} \mathrm{Cl}_{2}\right)$ $\bar{v}=3735.7,3649.3,3283.2,1640.0,1557.9,1393.9 \mathrm{~cm}^{-1} .{ }^{1} \mathrm{H}$ NMR $\left(300 \mathrm{MHz}, \mathrm{DMSO}-d_{6}\right) \delta: 8.87(\mathrm{t}$, $J=5.95 \mathrm{~Hz}, 1 \mathrm{H}, \mathrm{NH}), 7.54\left(\mathrm{~d}, J=1.98 \mathrm{~Hz}, 1 \mathrm{H}, \mathrm{H}-7^{\prime \prime}\right), 7.48\left(\mathrm{~d}, J=8.64 \mathrm{~Hz}, 1 \mathrm{H}, \mathrm{H}-4^{\prime \prime}\right), 7.23(\mathrm{~m}, 5 \mathrm{H}$, $\left.\mathrm{H}-3^{\prime}, 4^{\prime}, 5^{\prime \prime}\right), 4.25\left(\mathrm{~d}, J=5.95 \mathrm{~Hz}, 2 \mathrm{H}, \mathrm{H}-1^{\prime}\right), 4.11(\mathrm{~s}, 2 \mathrm{H}, \mathrm{H}-2) .{ }^{13} \mathrm{C}$ NMR $\left(75 \mathrm{MHz}, \mathrm{DMSO}-d_{6}\right) \delta 167.5$ 
(C-1), 152.1 (C-2') 139.4 (C-7a"), 138.4 (C-2'), 136.9 (C-4a"), $131.7\left(\mathrm{C}-5^{\prime}\right), 129.4\left(\mathrm{C}-3^{\prime}\right), 128.5$ (C-4'),

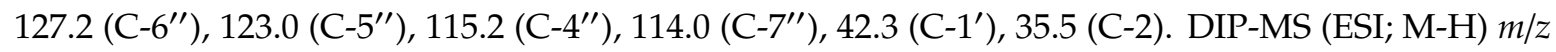
(calculated): $364.00, \mathrm{~m} / \mathrm{z}$ (measured): 363.95 .

6-chloro-2- (Nonylthio) -1H-Benzimidazole, 18c

Yield: $70 \%$. Pink solid; m.p. $73-76{ }^{\circ} \mathrm{C} . R_{\mathrm{f}}=0.66$ (hexane/AcOEt 7:3). IR $\left(\mathrm{CH}_{2} \mathrm{Cl}_{2}\right) \bar{v}=3032.6$, $1389.6 \mathrm{~cm}^{-1} .{ }^{1} \mathrm{H} \mathrm{NMR}\left(300 \mathrm{MHz}, \mathrm{CDCl}_{3}\right) \delta: 9.891(\mathrm{~s}, 1 \mathrm{H}, \mathrm{NH}), 7.51(\mathrm{~d}, J=1.97 \mathrm{~Hz}, 1 \mathrm{H}, \mathrm{H}-7)$, $7.42(\mathrm{~d}, J=8.56 \mathrm{~Hz}, 1 \mathrm{H}, \mathrm{H}-4), 7.16(\mathrm{dd}, J=8.56,1.97 \mathrm{~Hz}, 1 \mathrm{H}, \mathrm{H}-5), 3.28\left(\mathrm{~m}, 2 \mathrm{H}, \mathrm{H}-1^{\prime}\right), 1.72(\mathrm{~m}, 2 \mathrm{H}$, H-2'), 1.28 (m, 12H, H-3', $\left.4^{\prime}, 5^{\prime}, 6^{\prime}, 7^{\prime}, 8^{\prime}\right), 0.85\left(\mathrm{t}, J=6.83 \mathrm{~Hz}, 3 \mathrm{H}, \mathrm{H}-9^{\prime}\right) .{ }^{13} \mathrm{C} \mathrm{NMR}\left(75 \mathrm{MHz}, \mathrm{CDCl}_{3}\right) \delta$ 152.6 (C-2), 139.9 (C-7a), 137.9 (C-4a), 127.9 (C-6), 122.7 (C-5), 114.6 (C-4), 113.9 (C-7), 32.7 (C-1'), 31.8 , $29.6\left(\mathrm{C}-2^{\prime}\right), 29.4,29.2,29.1\left(\mathrm{C}-3^{\prime}\right), 28.7\left(\mathrm{C}-4^{\prime}\right), 22.7,14.1$ (C-9'). DIP-MS (ESI; M-H) $\mathrm{m} / z$ (calculated): $309.11, \mathrm{~m} / \mathrm{z}$ (measured): 309.05 .

\subsection{Procedure for the Synthesis of Compounds, $\mathbf{1 9}$}

In a vial for microwave reaction equipped with a magnetic stirring bar, a mixture was made of 5-chloro-2-aminopyridine ( $3.11 \mathrm{mmol}, 1 \mathrm{eq})$ and $2.5 \mathrm{~mL}$ of carboxylic acid (butanoic, hexanoic, nonanoic acids). The vial was closed, and the reaction mixture heated for $90 \mathrm{~min}$ (butanoic acid at $150{ }^{\circ} \mathrm{C}$, hexanoic acid at $150^{\circ} \mathrm{C}$, nonanoic acid at $180^{\circ} \mathrm{C}$ ). Upon completion of that period, the reaction mixture was transferred to a $20 \%$ potassium carbonate solution $(40 \mathrm{~mL})$ and left to stir for $30 \mathrm{~min}$ before being vacuum filtered. The solid was washed with $40 \mathrm{~mL}$ of distilled water in two portions of $20 \mathrm{~mL}$ and oven-dried at $40^{\circ} \mathrm{C}$.

N-(5-Chloropyridin-2-yl) Butamide, 19a

Yield: $91 \%$. White solid; m.p. $102-104{ }^{\circ} \mathrm{C} . R_{\mathrm{f}}=0.64$ (hexane/AcOEt 7:3). IR $\left(\mathrm{CH}_{2} \mathrm{Cl}_{2}\right) \bar{v}=3300.9$, 1697.8, $1582.4 \mathrm{~cm}^{-1} .{ }^{1} \mathrm{H}$ NMR $\left(300 \mathrm{MHz}, \mathrm{CDCl}_{3}\right) \delta: 8.41(\mathrm{~s}, 1 \mathrm{H}, \mathrm{NH}), 8.22\left(\mathrm{~d}, J=8.95 \mathrm{~Hz}, 1 \mathrm{H}, \mathrm{H}-3^{\prime}\right)$, $8.19\left(\mathrm{~d}, J=2.54 \mathrm{~Hz}, 1 \mathrm{H}, \mathrm{H}-6^{\prime}\right), 7.65\left(\mathrm{dd}, J=8.95,2.54 \mathrm{~Hz}, 1 \mathrm{H}, \mathrm{H}-4^{\prime}\right), 2.36(\mathrm{t}, J=7.43 \mathrm{~Hz}, 2 \mathrm{H}, \mathrm{H}-2)$, $1.74(\mathrm{~m}, 2 \mathrm{H}, \mathrm{H}-3), 0.98(\mathrm{t}, J=7.38 \mathrm{~Hz}, 3 \mathrm{H}, \mathrm{H}-4)$. DIP-MS (ESI; $\mathrm{M}+\mathrm{Na}) \mathrm{m} / \mathrm{z}$ (calculated): 221.04, $\mathrm{m} / \mathrm{z}$ (measured): 221.07 .

$N$-(5-Chloropyridin-2-yl) Hexanamide, 19b

Yield: $87 \%$. White solid; m.p. $103-106^{\circ} \mathrm{C} . R_{\mathrm{f}}=0.73$ (hexane/AcOEt 7:3). IR $\left(\mathrm{CH}_{2} \mathrm{Cl}_{2}\right) \bar{v}=3275.3$, 1690.5, $1582.3 \mathrm{~cm}-1$. NMR 1H (600 MHz, $\left.\mathrm{CDCl}_{3}\right) \delta: 8.37$ (s, 1H, NH), $8.23\left(\mathrm{~d}, J=8.9 \mathrm{~Hz}, 1 \mathrm{H}, \mathrm{H}-3^{\prime}\right)$, $8.21\left(\mathrm{~d}, J=2.5 \mathrm{~Hz}, 1 \mathrm{H}, \mathrm{H}-6^{\prime}\right), 7.66\left(\mathrm{dd}, J=8.9,2.5 \mathrm{~Hz}, 1 \mathrm{H}, \mathrm{H}-4^{\prime}\right), 2.49(\mathrm{t}, J=7.58 \mathrm{~Hz}, 2 \mathrm{H}, \mathrm{H}-2), 1.73(\mathrm{~m}$, 2H, H-3), 1.35 (m, 4H, H-4,5), 0.90 (t, J = 7.13 Hz, 3H, H-6). NMR 13C (125 MHz, CDCl $) \delta 171.9(\mathrm{C}-1)$, 149.9 (C-2') $146.3\left(\mathrm{C}-6^{\prime}\right), 138.0\left(\mathrm{C}-4^{\prime}\right), 126.5\left(\mathrm{C}-5^{\prime}\right), 114.8\left(\mathrm{C}-3^{\prime}\right), 37.7$ (C-2), 31.3 (C-4), 25.0 (C-3), 22.4 (C-5), 13.9 (C-6). DIP-MS (ESI; M+Na) m/z (calculated): 249.07, $\mathrm{m} / \mathrm{z}$ (measured): 249.11.

\section{$\mathrm{N}$-(5-Chloropyridin-2-yl) Nonamide, 19c}

Yield: $90 \%$. White solid; m.p. $64-66^{\circ} \mathrm{C} . R_{\mathrm{f}}=0.8$ (hexane/AcOEt 7:3). IR $\left(\mathrm{CH}_{2} \mathrm{Cl}_{2}\right) \bar{v}=3271.7$, 1687.1, $1582.7 \mathrm{~cm}^{-1} .{ }^{1} \mathrm{H}$ NMR (600 MHz, $\left.\mathrm{CDCl}_{3}\right) \delta: 8.874(\mathrm{~s}, 1 \mathrm{H}, \mathrm{NH}), 8.25\left(\mathrm{~d}, J=8.88 \mathrm{~Hz}, 1 \mathrm{H}, \mathrm{H}-3^{\prime}\right)$, $8.19\left(\mathrm{~d}, J=2 \mathrm{~Hz}, 1 \mathrm{H}, \mathrm{H}-6^{\prime}\right), 7.64\left(\mathrm{dd}, J=8.88,2 \mathrm{~Hz}, 1 \mathrm{H}, \mathrm{H}-4^{\prime}\right), 2.38(\mathrm{t}, J=7.59 \mathrm{~Hz}, 2 \mathrm{H}, \mathrm{H}-2), 1.70(\mathrm{~m}, 2 \mathrm{H}$, $\mathrm{H}-3), 1.28$ (m, 10H, H-4,5,6,7,8), 0.85 (t, $J=6.88 \mathrm{~Hz}, 3 \mathrm{H}, \mathrm{H}-9) .{ }^{13} \mathrm{C}$ NMR $\left(125 \mathrm{MHz}, \mathrm{CDCl}_{3}\right) \delta 172.1$ (C-1), 150.1 (C-2'), 146.1 (C-6'), 138.7 (C-4'), 126.5 (C-5'), 115.0 (C-3'), 37.6 (C-2), 31.8, 29.3, 29.2, 29.1, 25.3 (C-3), 22.6, 14.0 (C-9). DIP-MS (ESI; M+Na) $m / z$ (calculated): 291.12, $\mathrm{m} / \mathrm{z}$ (measured): 291.19.

\subsection{Procedure for the Synthesis of N-Substituted 2-(4-formylphenoxy) Acetamides, 35}

In a $50 \mathrm{~mL}$ ball flask loaded with magnetic stirring bar, $15 \mathrm{~mL}$ of $\mathrm{CH}_{2} \mathrm{Cl}_{2}$, the corresponding amine ( $3.91 \mathrm{mmol}, 1 \mathrm{eq})$ and bromine acetyl bromide $(4.70 \mathrm{mmol}, 1.2 \mathrm{eq})$ were added. The reaction mixture was stirred at $\mathrm{rt}$ for $20 \mathrm{~min}$. Subsequently, $40 \mathrm{~mL}$ of a $20 \%$ aqueous sodium carbonate solution was added and separated by liquid-liquid extraction with $\mathrm{CH}_{2} \mathrm{Cl}_{2}(2 \times 10 \mathrm{~mL})$. The combined organic phases were 
dried with anhydrous $\mathrm{Na}_{2} \mathrm{SO}_{4}$ and filtered, then evaporated under vacuum. Once the residue was dry, it was transferred to a $100 \mathrm{~mL}$ ball flask equipped with a magnetic stirring bar and reacted with 4-hydroxybenzaldehyde ( $4.31 \mathrm{mmol}, 1.1 \mathrm{eq})$ and DBU ( $3.91 \mathrm{mmol}, 1 \mathrm{eq})$ at $70{ }^{\circ} \mathrm{C}$ for $6 \mathrm{~h}$, employing acetonitrile $(20 \mathrm{~mL})$ as solvent. Upon completion of that period, the solvent was evaporated under reduced pressure, and $30 \mathrm{~mL}$ of a $5 \% \mathrm{HCl}$ solution was added to the residue. Afterwards liquid-liquid extractions were carried out with $\mathrm{AcOEt}(3 \times 10 \mathrm{~mL})$ and the organic phases were dried with anhydrous $\mathrm{Na}_{2} \mathrm{SO}_{4}$ and filtered. The filtrate was evaporated under reduced pressure and the residue was purified by column chromatography, with silica gel as a stationary phase and a hexane/AcOEt mixture 7: 3 as the mobile phase.

N-(3-Chlorophenyl)-2-(4-Formylphenoxy) Acetamide, 35a

Yield: $65 \%$. White solid. ${ }^{1} \mathrm{H}$ NMR $\left(600 \mathrm{MHz}, \mathrm{DMSO}-d_{6}\right) \delta: 10.364(\mathrm{~s}, 1 \mathrm{H}, \mathrm{NH}), 9.89(\mathrm{~s}, 1 \mathrm{H}$, $\mathrm{CHO}), 7.90\left(\mathrm{~d}, J=8.77 \mathrm{~Hz}, 2 \mathrm{H}, \mathrm{H}-3^{\prime \prime}\right), 7.85\left(\mathrm{t}, J=1.81 \mathrm{~Hz}, 1 \mathrm{H}, \mathrm{H}-2^{\prime}\right), 7.55\left(\mathrm{~d}, J=8.11 \mathrm{~Hz}, 1 \mathrm{H}, \mathrm{H}-6^{\prime}\right)$, $7.35\left(\mathrm{t}, J=8.11 \mathrm{~Hz}, 1 \mathrm{H}, \mathrm{H}-5^{\prime}\right), 7.20\left(\mathrm{~d}, J=8.77 \mathrm{~Hz}, 2 \mathrm{H}, \mathrm{H}-2^{\prime \prime}\right), 7.14\left(\mathrm{~d}, J=8.11 \mathrm{~Hz}, 1 \mathrm{H}, \mathrm{H}-4^{\prime}\right), 4.89(\mathrm{~s}, 2 \mathrm{H}$, H-2). ${ }^{13} \mathrm{C}$ NMR (150 MHz, DMSO-d $\left.d_{6}\right) \delta$ 191,7 (CHO), 166.8 (C-1), $163.1\left(\mathrm{C}-1^{\prime \prime}\right), 140.2\left(\mathrm{C}-1^{\prime}\right), 133.6\left(\mathrm{C}-3^{\prime}\right)$, $132.2\left(\mathrm{C}-3^{\prime \prime}\right), 130.9\left(\mathrm{C}-5^{\prime}\right), 130.6\left(\mathrm{C}-4^{\prime \prime}\right), 123.9\left(\mathrm{C}-4^{\prime}\right), 119.7\left(\mathrm{C}-2^{\prime}\right), 118.5\left(\mathrm{C}-6^{\prime}\right), 115.6\left(\mathrm{C}-2^{\prime \prime}\right), 67.5(\mathrm{C}-2)$. DIP-MS (ESI; M-H) $m / z$ (calculated): 288.04, $m / z$ (measured): 288.05 .

$\mathrm{N}$-(4-Chlorobenzyl)-2-(4-Formylphenoxy) Acetamide, 35b

Yield: 73\%. White solid. ${ }^{1} \mathrm{H}$ NMR (600 MHz, DMSO- $\left.d_{6}\right) \delta: 9.98(\mathrm{~s}, 1 \mathrm{H}, \mathrm{CHO}), 8.77(\mathrm{t}, J=6 \mathrm{~Hz}$, $1 \mathrm{H}, \mathrm{NH}), 7.89\left(\mathrm{~d}, J=8.7 \mathrm{~Hz}, 2 \mathrm{H}, \mathrm{H}-3^{\prime \prime}\right), 7.37\left(\mathrm{~d}, J=8.4 \mathrm{~Hz}, 2 \mathrm{H}, \mathrm{H}-4^{\prime}\right), 7.29\left(\mathrm{~d}, J=8.4 \mathrm{~Hz}, 2 \mathrm{H}, \mathrm{H}-3^{\prime}\right)$, $7.16\left(\mathrm{~d}, J=8.7 \mathrm{~Hz}, 2 \mathrm{H}, \mathrm{H}-2^{\prime \prime}\right), 4.71(\mathrm{~s}, 2 \mathrm{H}, \mathrm{H}-2), 4.34\left(\mathrm{~d}, J=6 \mathrm{~Hz}, 2 \mathrm{H}, \mathrm{H}-1^{\prime}\right) .{ }^{13} \mathrm{C}$ NMR $(150 \mathrm{MHz}$, DMSO-d 6 ) $\delta 191.3(\mathrm{CHO}), 167.2(\mathrm{C}-1), 162.5\left(\mathrm{C}-1^{\prime \prime}\right), 138.2\left(\mathrm{C}-2^{\prime}\right), 131.6\left(\mathrm{C}-3^{\prime \prime}\right), 131.3\left(\mathrm{C}-5^{\prime}\right), 130.1\left(\mathrm{C}-4^{\prime \prime}\right)$, $129.0\left(\mathrm{C}-3^{\prime}\right), 128.1\left(\mathrm{C}-4^{\prime}\right), 115.2\left(\mathrm{C}-2^{\prime \prime}\right), 66.9$ (C-2), 41.1 (C-1'). DIP-MS (ESI; M-H) $m / z$ (calculated): 302.05, $\mathrm{m} / \mathrm{z}$ (measured): 302.09 .

\section{2-(4-Formylphenoxy)- $\mathrm{N}$-propyl Acetamide, 35c}

Yield: 79\%. White solid. ${ }^{1} \mathrm{H}$ NMR (500 MHz, DMSO- $\left.d_{6}\right) \delta: 9.87(\mathrm{~s}, 1 \mathrm{H}, \mathrm{CHO}), 8.15(\mathrm{~s}, 1 \mathrm{H}, \mathrm{NH})$, $7.87\left(\mathrm{~d}, J=8.7 \mathrm{~Hz}, 2 \mathrm{H}, \mathrm{H}-3^{\prime \prime}\right), 7.13\left(\mathrm{~d}, J=8.7 \mathrm{~Hz}, 2 \mathrm{H}, \mathrm{H}-2^{\prime \prime}\right), 4.60(\mathrm{~s}, 2 \mathrm{H}, \mathrm{H}-2), 3.08$ (dd, $J=13.15$, 6.84, 2H, H-1' $), 1.44\left(\mathrm{~m}, 2 \mathrm{H}, \mathrm{H}-2^{\prime}\right), 0.82\left(\mathrm{t}, J=7.42 \mathrm{~Hz}, 3 \mathrm{H}, \mathrm{H}-3^{\prime}\right) .{ }^{13} \mathrm{C}$ NMR $\left(125 \mathrm{MHz}, \mathrm{DMSO}-d_{6}\right) \delta$ 191.786 (CHO), 167.3 (C-1), 163.1 (C-1" $), 132.1\left(\mathrm{C}-3^{\prime \prime}\right), 130.5$ (C-4" $), 115.6\left(\mathrm{C}-2^{\prime \prime}\right), 67.5(\mathrm{C}-2), 40.6\left(\mathrm{C}-1^{\prime}\right)$, 22.8 (C-2'), 11.7 (C-3'). DIP-MS (ESI; M + Na) m/z (calculated): 244.09, m/z (measured): 244.10.

\subsection{Synthesis of N-Substituted 2-(4-(imidazolin-2-yl)-phenoxy) Acetamides, 32}

Once the aldehydes ( $1.20 \mathrm{mmol}, 1 \mathrm{eq})$ were obtained, they were placed in a $100 \mathrm{~mL}$ ball flask containing $50 \mathrm{~mL}$ of acetonitrile. Afterwards, they were subjected to a reaction with ethylenediamine (1.20 mmol, $1 \mathrm{eq}$ ) with ultrasound for $15 \mathrm{~min}$. Upon completion of this time, NBS (1.45 mmol, $1.2 \mathrm{Eq})$ was added to the reaction mixture and it was reacted by ultrasound for $10 \mathrm{~min}$. Then the solvent was evaporated under reduced pressure, followed by the addition of $30 \mathrm{~mL}$ of an aqueous solution of $20 \%$ $\mathrm{NaOH}$. The resulting suspension was stirred for $20 \mathrm{~min}$ and vacuum filtered. The solid obtained was washed with $40 \mathrm{~mL}$ of distilled water $(2 \times 20 \mathrm{~mL})$ and oven-dried at $40{ }^{\circ} \mathrm{C}$.

N-(3-Chlorophenyl)-2-(4-(Imidazolin-2-yl) Phenoxy) Acetamide, 32a

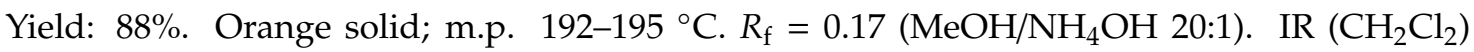
$\bar{v}=3584.6,3203,1655.9,1532.8 \mathrm{~cm}-1 .{ }^{1} \mathrm{H}$ NMR $\left(500 \mathrm{MHz}, \mathrm{DMSO}-d_{6}\right) \delta: 10.47(\mathrm{~s}, 1 \mathrm{H}, \mathrm{NH})$, $7.84\left(\mathrm{t}, J=1.99 \mathrm{~Hz}, 1 \mathrm{H}, \mathrm{H}-2^{\prime}\right), 7.77\left(\mathrm{~d}, J=8.7 \mathrm{~Hz}, 2 \mathrm{H}, \mathrm{H}-3^{\prime \prime}\right), 7.54\left(\mathrm{~m}, 1 \mathrm{H}, \mathrm{H}-6^{\prime}\right), 7.33(\mathrm{t}, J=8.12 \mathrm{~Hz}, 1 \mathrm{H}$, $\left.\mathrm{H}-5^{\prime}\right), 7.13\left(\mathrm{~m}, 1 \mathrm{H}, \mathrm{H}-4^{\prime}\right), 7.03$ (d, $\left.J=8.7 \mathrm{~Hz}, 2 \mathrm{H}, \mathrm{H}-2^{\prime \prime}\right), 4.77$ (s, 2H, H-2), 3.56 (s, 4H, H-7"). ${ }^{13} \mathrm{C} \mathrm{NMR}$ (125 MHz, DMSO-d $\left.d_{6}\right) \delta 167.2(\mathrm{C}-1), 163.6\left(\mathrm{C}-5^{\prime \prime}\right), 159.7\left(\mathrm{C}-1^{\prime \prime}\right), 140.3\left(\mathrm{C}-1^{\prime}\right), 133.5\left(\mathrm{C}-3^{\prime}\right), 130.9\left(\mathrm{C}-5^{\prime}\right)$, $129.1\left(\mathrm{C}-3^{\prime \prime}\right), 124.3\left(\mathrm{C}-4^{\prime \prime}\right), 123.8\left(\mathrm{C}-4^{\prime}\right), 119.6\left(\mathrm{C}-2^{\prime}\right), 118.5\left(\mathrm{C}-6^{\prime}\right), 114.7\left(\mathrm{C}-2^{\prime \prime}\right), 67.4(\mathrm{C}-2), 49.9$ (C-7' $)$. DIP-MS (ESI; $\left.\mathrm{M}-\mathrm{H}_{2} \mathrm{O}+\mathrm{MeOH}\right) \mathrm{m} / \mathrm{z}$ (calculated): 344.11, $\mathrm{m} / \mathrm{z}$ (measured): 344.20 . 
N-(4-Chlorobenzyl)-2-(4-(Imidazolin-2-yl) Phenoxy) Acetamide, 32b

Yield: $90 \%$. Yellow solid; m.p. $149-155^{\circ} \mathrm{C} . R_{\mathrm{f}}=0.2\left(\mathrm{MeOH} / \mathrm{NH}_{4} \mathrm{OH} 20: 1\right) . \operatorname{IR}\left(\mathrm{CH}_{2} \mathrm{Cl}_{2}\right) \bar{v}=3250.1$, 1594.5, 1545.1, 1516.9, 839.1 cm ${ }^{-1} .{ }^{1} \mathrm{H}$ NMR $\left(500 \mathrm{MHz}\right.$, DMSO- $\left.d_{6}\right) \delta: 8.74(\mathrm{t}, J=6.14 \mathrm{~Hz}, 1 \mathrm{H}, \mathrm{NH})$, $7.79\left(\mathrm{~d}, J=8.78 \mathrm{~Hz}, 2 \mathrm{H}, \mathrm{H}-3^{\prime \prime}\right), 7.38\left(\mathrm{~d}, J=8.4 \mathrm{~Hz}, 2 \mathrm{H}, \mathrm{H}-4^{\prime}\right), 7.29\left(\mathrm{~d}, J=8.4 \mathrm{~Hz}, 2 \mathrm{H}, \mathrm{H}-3^{\prime}\right), 7.02(\mathrm{~d}$, $\left.J=8.78 \mathrm{~Hz}, 2 \mathrm{H}, \mathrm{H}-2^{\prime \prime}\right), 4.62(\mathrm{~s}, 2 \mathrm{H}, \mathrm{H}-2), 4.35$ (d, J = 6.14 Hz, 2H, H-1'), 3.59 (s, 4H, H-7'). ${ }^{13} \mathrm{C}$ NMR $\left(125 \mathrm{MHz}, \mathrm{DMSO}-d_{6}\right) \delta 168.1(\mathrm{C}-1), 163.6\left(\mathrm{C}-5^{\prime \prime}\right), 159.6\left(\mathrm{C}-1^{\prime \prime}\right), 138.8\left(\mathrm{C}-2^{\prime}\right), 131 .\left(\mathrm{C}-5^{\prime}\right), 129.6\left(\mathrm{C}-3^{\prime}\right)$, $129.1\left(\mathrm{C}-3^{\prime \prime}\right), 128.6\left(\mathrm{C}-4^{\prime}\right), 124.3\left(\mathrm{C}-4^{\prime \prime}\right), 114.8\left(\mathrm{C}-2^{\prime \prime}\right), 67.4(\mathrm{C}-2), 49.8\left(\mathrm{C}-7^{\prime \prime}\right), 41.7$ (C-1'). DIP-MS (ESI; $\mathrm{M}+\mathrm{H}) \mathrm{m} / \mathrm{z}$ (calculated): $344.11, \mathrm{~m} / \mathrm{z}$ (measured): 344.02 .

2-(4-(Imidazolin-2-yl) Phenoxy)-N-Propyl Acetamide, 32c

Yield: $85 \%$. White solid); m.p. $175-178^{\circ} \mathrm{C} . R_{\mathrm{f}}=0.15\left(\mathrm{MeOH} / \mathrm{NH}_{4} \mathrm{OH} 20: 1\right) . \mathrm{IR}\left(\mathrm{CH}_{2} \mathrm{Cl}_{2}\right) \bar{v}=3376.1$, 3202.8, 1659.4, 1615.4, 1537.3, $1519.5 \mathrm{~cm}-1 .{ }^{1} \mathrm{H}$ NMR (500 MHz, DMSO- $\left.d_{6}\right) \delta: 8.10(\mathrm{t}, J=5.36 \mathrm{~Hz}$, $1 \mathrm{H}, \mathrm{NH}), 7.75\left(\mathrm{~m}, 2 \mathrm{H}, \mathrm{H}-3^{\prime \prime}\right), 6.91\left(\mathrm{~m}, 2 \mathrm{H}, \mathrm{H}-2^{\prime \prime}\right), 4.50(\mathrm{~s}, 2 \mathrm{H}, \mathrm{H}-2), 3.56\left(\mathrm{~s}, 4 \mathrm{H}, \mathrm{H}-7^{\prime \prime}\right), 3.08(\mathrm{~m}, 2 \mathrm{H}$, $\left.\mathrm{H}-1^{\prime}\right), 1.43\left(\mathrm{~m}, 2 \mathrm{H}, \mathrm{H}-2^{\prime}\right), 0.81\left(\mathrm{t}, J=7.42 \mathrm{~Hz}, 3 \mathrm{H}, \mathrm{H}-3^{\prime}\right) .{ }^{13} \mathrm{C}$ NMR $\left(125 \mathrm{MHz}\right.$, DMSO- $\left.d_{6}\right) \delta 167.7(\mathrm{C}-1)$, $163.6\left(\mathrm{C}-5^{\prime \prime}\right), 159.6\left(\mathrm{C}-1^{\prime \prime}\right), 129.0\left(\mathrm{C}-3^{\prime \prime}\right), 124.1\left(\mathrm{C}-4^{\prime \prime}\right), 114.7\left(\mathrm{C}-2^{\prime \prime}\right), 67.4(\mathrm{C}-2), 49.7\left(\mathrm{C}-7^{\prime \prime}\right), 40.5\left(\mathrm{C}-1^{\prime}\right)$, 22.8 (C-2'), 11.7 (C-3'). DIP-MS (ESI; M+H) m/z (calculated): 262.15, $\mathrm{m} / z$ (measured): 262.04 .

\subsection{Preparation of Culture Media, Test Compounds, and Inoculum}

The Luria Bertani (LB) broth was prepared in one liter of distilled water by adding $10 \mathrm{~g}$ peptone, $5 \mathrm{~g}$ yeast extract, and $5 \mathrm{~g} \mathrm{NaCl}$ and then sterilized in an autoclave at $15 \mathrm{psi}$ and $121^{\circ} \mathrm{C}$ for $15 \mathrm{~min}$. For the LB solid medium, $15 \mathrm{~g}$ of bacteriological agar was added and the solution was made up to a liter with distilled water. Thioglycolate medium BBL was prepared according to the fabricant specifications with distilled water and then sterilized in an autoclave at $15 \mathrm{psi}$ and $121^{\circ} \mathrm{C}$ for $15 \mathrm{~min}$. C. violaceum CV026 was always grown in the presence of $30 \mu \mathrm{g} / \mathrm{mL}$ of kanamycin.

The amount of each test compound required for a concentration of $100 \mathrm{mM}$ Pleasewas weighed. With the resulting solution, serial 1:10 dilutions were prepared to obtain concentrations $1000 \mu \mathrm{M}$, $100 \mu \mathrm{M}$ and $10 \mu \mathrm{M}$.

\subsection{Preparation of CV026 Suspensions}

C. violaceum CV026 from a cryovial was streaked onto L-agar plates containing $30 \mu \mathrm{g} / \mathrm{mL}$ kanamycin. Bacteria were incubated at $29^{\circ} \mathrm{C}$ for $24 \mathrm{~h}$. The next day an isolated colony was inoculated into $5 \mathrm{~mL} \mathrm{LB}$ medium with $30 \mu \mathrm{g} / \mathrm{mL}$ kanamycin, followed by incubation at $29^{\circ} \mathrm{C}$ and $200 \mathrm{rpm}$ for $15 \mathrm{~h}$.

\subsection{Evaluation of Compounds as Quorum Sensing Inhibitors in Chromobacterium violaceum CV026}

C. violaceum $\mathrm{CV} 026$ was cultured in $50 \mathrm{~mL}$ of thioglycolate medium until reaching an optical density of 0.12 to $600 \mathrm{~nm}$, then $430 \mu \mathrm{L}$ of an $80 \mu \mathrm{M}$ C6-AHL solution were added ( $680 \mathrm{nM}$ final concentration) to the broth. Subsequently $1980 \mu \mathrm{L}$ of the suspension was transferred to a $5 \mathrm{~mL}$ tube and $20 \mu \mathrm{L}$ of the dilutions of the test compounds were added until reaching the final concentration of $1000 \mu \mathrm{M}, 100 \mu \mathrm{M}, 10 \mu \mathrm{M}$. Tubes were incubated at $29^{\circ} \mathrm{C}$ and $800 \mathrm{rpm}$ for $16 \mathrm{~h}$. Upon completion of the incubation time, cell density was determined by absorbance at $720 \mathrm{~nm}$ by using the thioglycolate medium as the blank. Finally, the absorbance of violacein was measured. $500 \mu \mathrm{L}$ of the bacterial culture was placed in a $2 \mathrm{~mL}$ tube and then $500 \mu \mathrm{L}$ of acetone were added. The tubes were vortexed and centrifuged at 15,000 rpm for $1 \mathrm{~min}$. The specific production of violacein was calculated by dividing the value of the reading at $577 \mathrm{~nm}$ by that at $720 \mathrm{~nm}$. Experiments with additional concentrations were performed in order to determinate the $\mathrm{IC}_{50}$ values. Each experiment was performed 6 times/compound, and the results were graphed. Statistical significance was analyzed by Student's $t$-test.

\subsection{Modeling and Optimization of Ligands.}

Docking studies of the target compounds were carried out on the CviR protein (PDB code: 3QP6). 
Prior to docking, the ligands were drawn with the ACD/ChemSketch program [51]. A geometric pre-optimization was created in 3D maintaining the stereochemistry. The 3D structures were submitted to a geometric and energetic optimization at the AM1 (Austin Model 1) semiempirical level using the Gaussian 09 program [52]. The output files were saved as (PDB).

\subsection{Molecular Docking}

The docking studies were performed on the AutoDock 4.2 program, which maintains the macromolecule rigid while allowing flexibility in the ligand. Polar hydrogens were added to the ligand, and protein atoms and partial charges were assigned to the receptor (Kollman) and ligand (Gasteiger). Blind docking was achieve using a grid box of $126 \AA^{3}$ with a grid spacing of $0.375 \AA^{3}$ using the Hybrid Genetic Algorithm of Lamarckian with an initial population of 100 randomized individuals and a maximum number of energy evaluations of $10^{7}$. The results of these docking simulations experiments were examined on AutoDockTools version 1.5.2 and PyMol visualizer to describe the non-bond interaction from the ligand-protein complex.

\section{Conclusions}

Compounds 16a-c, 17a-c, 18a-c, 19a-c and 32a-c were synthesized in moderate to very good global yields, finding MW energy and ultrasound to be extremely useful for the corresponding reactions. The synthesis of the ethyl 2-acylamino thiazole-4-carboxylate 16a-c, was improved using MW in the acylation of the electronically deactivated amino, obtaining higher yields than those reported previously. A methodology was established in the current contribution for the synthesis of $\mathrm{N}$-[4-(thiazolin-2-yl) -phenyl]-carboxamides using MW as an energy source and obtaining 3 new compounds. Three novel benzimidazoles 18a-c were synthesized. A new methodology was developed for the synthesis of $N$-(5-chloropyridin-2-yl) amides using MW, obtaining higher yields than those in reported procedures and in shorter times. A new methodology was established for the synthesis of $\alpha$-phenoxy-imidazolin-2-yl acetamides, involving better yields and shorter times at all reaction stages and achieving 3 new compounds, 32a-c.

Docking and biological data were in good agreement, which confirms that $16 \mathbf{b}-\mathbf{c}, 17 \mathbf{a}-\mathbf{c}, 18 \mathbf{a}-\mathbf{c}$, 19a-c, and 32a-c conduct as bioisosteres of AHL. Such behavior is not attributed to the atom-by-atom or group by group interaction of these compounds with the CviR protein, but rather to the total supramolecular interplay of the compounds with the receptor. Nevertheless, the importance of the $\pi-\pi$ interactions emphasizes the fundamental role of the aromatic ring in the inhibitory activity.

The inhibitory activity of quorum sensing shown by the active compounds ranges from low to good, highlighting the activities of benzimidazole 18a and pyridine 19c.

Supplementary Materials: Supplementary materials can be found at http://www.mdpi.com/1422-0067/21/24/ 9512/s1.

Author Contributions: Conceptualization, A.R.-A.; methodology, A.R.-A., E.C.-Q. and J.C.-B.; software, J.C.-B., A.R.-A., and A.F.-G.; validation, A.R.-A., E.C.-Q. and J.C.-B.; formal analysis, A.R.-A., E.C.-Q., J.C.-B., A.F.-G.; investigation, A.F.-G., A.M.-M., E.C.-Q., A.R.-A.; resources, A.R.-A., E.C.-Q. and J.C.-B.; data curation, A.R.-A.; writing-original draft preparation, A.F.-G., A.R.-A., E.C.-Q. and J.C.-B.; writing-review and editing, A.R.-A.; visualization, A.R.-A.; supervision, A.R.-A.; project administration, A.R.-A.; funding acquisition, A.R.-A. All authors have read and agreed to the published version of the manuscript.

Funding: This research was funded by Conacyt, grants 240808 and 255420, and "IPN through grant 20201304".

Acknowledgments: We acknowledge Rogelio Rojas Ríos and Carlos Alcides Chávez Soriano for supporting the biological evaluation, María Isabel Díaz Contador for supporting statistics and Centro de Instrumentación of Escuela Nacional de Ciencias Biológicas for IR Spectra. A.F.-G thanks Conacyt México and IPN for scholarships.

Conflicts of Interest: The authors declare no conflict of interest. 


\section{Abbreviations, Acronyms and Symbols}

$\begin{array}{ll}\text { QS } & \text { quorum sensing } \\ \text { QSI } & \text { quorum sensing inhibitor } \\ \text { QSIs } & \text { quorum sensing inhibitors } \\ \text { AHL } & \text { microwave irradiation } \\ \text { MW } & \text { microwave irradiation } \\ \Delta G & \text { affinity energy } \\ \text { UV } & \text { ultraviolet } \\ \text { IR } & \text { infrared } \\ \text { ग) } & \text { Ultrasound } \\ \text { NMR } & \text { Nuclear Magnetic Resonance } \\ \text { DIP-MS } & \text { Direct Insertion Probe-Mass Spectrometry } \\ \text { ESI } & \text { Electrospray Ionization }\end{array}$

\section{References}

1. Steed, J.W.; Atwood, J.L. Supramolecular Chemistry; John Willey \&Sons, Ltd.: Oxford, UK, 2009 ; p. 85. ISBN 978-0-470-51233-3.

2. Whiteley, M.; Diggle, S.P.; Greenberg, E.P. Progress in and promise of bacterial quorum sensing research. Nature 2017, 551, 313-320. [CrossRef]

3. Holm, A.; Vikström, E. Quorum sensing communication between bacteria and human cells: Signals, targets, and functions. Front. Plant Sci. 2014, 5, 309. [CrossRef]

4. Papenfort, K.; Bassler, B.L. Quorum sensing signal-response systems in Gram-negative bacteria. Nat. Rev. Microbiol. 2016, 14, 576-588. [CrossRef]

5. de Kievit, T.R. Quorum sensing in Pseudomonas aeruginosa biofilms. Environ. Microbiol. 2009, 11, $279-288$. [CrossRef]

6. Jiang, Q.; Chen, J.; Yang, C.; Yin, Y.; Yao, K. Quorum sensing: A prospective therapeutic target for bacterial diseases. BioMed Res. Int. 2019, 2015978. [CrossRef]

7. Swem, L.R.; Swem, D.L.; O'Loughlin, C.T.; Gatmaitan, R.; Zhao, B.; Ulrich, S.M.; Bassler, B.L. A quorum-sensing antagonist targets both membrane-bound and cytoplasmic receptors and controls bacterial pathogenicity. Mol. Cell 2009, 35, 143-153. [CrossRef]

8. Pérez, P.D.; Hagen, S.J. Heterogeneous response to a quorum-sensing signal in the luminescence of individual Vibrio fischeri. PLoS ONE 2010, 5, 15473. [CrossRef]

9. McClean, K.H.; Winson, M.K.; Fish, L. Quorum sensing and Chromobacterium violaceum: Exploitation of violacein production and inhibition for the detection of N-acylhomoserine lactones. Microbiology 1997, 143, 3703-3711. [CrossRef]

10. Allen, L.; Dockrell, D.H.; Pattery, T. Pyocyanin production by Pseudomonas aeruginosa induces neutrophil apoptosis and impairs neutrophil-mediated host defenses in vivo. J. Immunol. 2005, 174, 3643-3649. [CrossRef] [PubMed]

11. Rémy, B.; Mion, S.; Plener, L.; Elias, M.; Chabrière, E.; Daudé, D. Interference in Bacterial Quorum Sensing: A Biopharmaceutical Perspective. Front. Pharmacol. 2018, 9, 203. [CrossRef] [PubMed]

12. Moreira, L.L.; Barreiro, E.J. A useful Strategy for Molecular Modification and Drug Design. Curr. Med. Chem. 2005, 1223-1249. [CrossRef]

13. Reyes-Arellano, A.; Bucio-Cano, A.; Salgado-Zamora, H.; Curiel-Quesada, E. Chapter: AHL bioisosteres as a strategy for minimizing or eliminating the virulence of gram-negative bacteria. In Microbial Pathogens and Strategies for Combating Them: Science, Technology and Education; Méndez-Vilas, A., Ed.; Formatex Research Center: Badajoz, Spain, 2013; Volume 1, pp. 204-215. ISBN 978-84-939843-9-7.

14. O'Loughlin, C.T.; Miller, L.C.; Siryaporn, A.; Drescher, K.; Semmelhack, M.F.; Bassler, B.L. A quorum-sensing inhibitor blocks Pseudomonas aeruginosa virulence and biofilm formation. Proc. Natl. Acad. Sci. USA 2013, 110, 17981-17986. [CrossRef]

15. Biswas, N.N.; Kutty, S.K.; Barraud, N. Indole-based novel small molecules for the modulation of bacterial signalling pathways. Org. Biomol. Chem. 2015, 13, 925-937. [CrossRef] [PubMed] 
16. Li, S.; Wawrzyniak, J.; Queneau, Y.; Soulère, L. 2-Substituted Aniline as a Simple Scaffold for LuxR-Regulated QS Modulation. Molecules 2017, 22, 2090. [CrossRef] [PubMed]

17. Liu, H.; Gong, Q.; Luo, C. Synthesis and Biological Evaluation of Novel L-Homoserine Lactone Analogs as Quorum Sensing Inhibitors of Pseudomonas aeruginosa. Chem. Pharm. Bull. 2019, 67, 1088-1098. [CrossRef]

18. Fong, J.; Mortensen, K.T.; Nørskov, A. Itaconimides as Novel Quorum Sensing Inhibitors of Pseudomonas aeruginosa. Front. Cell. Infect. Microbiol. 2019, 8, 443. [CrossRef] [PubMed]

19. Kothari, V.; Sharma, S.; Padia, D. Recent research advances on Chromobacterium violaceum. Asian Pac. J. Trop. Med. 2017, 10, 744-752. [CrossRef]

20. Bucio-Cano, A.; Reyes-Arellano, A.; Correa-Basurto, J. Targeting quorum sensing by designing azoline derivatives to inhibit the N-hexanoyl homoserine lactone-receptor CviR: Synthesis as well as biological and theoretical evaluations. Bioorg. Med. Chem. 2015, 23, 7565-7577. [CrossRef]

21. Herrera-Arizmendi, J.L.; Curiel-Quesada, E.; Correa-Basurto, J.; Bello, M.; Reyes-Arellano, A. Effect ofNewAnalogs of Hexyloxy Phenyl Imidazoline on Quorum Sensing in Chromobacterium violaceum and in Silico Analysis of Ligand-Receptor Interactions. J. Chem. 2020, 8735190. [CrossRef]

22. Wang, C.; Xu, P.; Zhang, L.; Huang, J.; Zhu, K.; Luo, C. Current Strategies and Applications for Precision Drug Design. Front. Pharmacol. 2018, 9, 787. [CrossRef]

23. Kitao, T.; Lepine, F.; Felici, A.; Rahme, L. Molecular Insights into Function and Competitive Inhibition of Pseudomonas aeruginosa Multiple Virulence Factor Regulator. mBio 2018, 9, e02158-17. [CrossRef] [PubMed]

24. Reyes-Arellano, A.; Bucio-Cano, A.; Montenegro-Sustaita, M.; Curiel-Quesada, E.; Salgado-Zamora, H. Imidazolines as non-classical bioisosteres of $\mathrm{N}$-acyl homoserine lactones and quorum sensing inhibitors. Int. J. Mol. Sci. 2012, 13, 1284-1299. [CrossRef] [PubMed]

25. Valiveti, A.; Bhalerao, U.; Halve, A.; Kaushik, M. Synthesis and in vitro kinetic evaluation of $\mathrm{N}$-thiazolylacetamido monoquaternary pyridinium oximes as reactivators of sarin, O-ethylsarin and VX inhibited human acetylcholinesterase (hAChE). Bioorg. Med. Chem. 2015, 23, 4899-4910. [CrossRef] [PubMed]

26. Kesicki, E.A.; Bailey, M.A.; Ovechkina, Y.; Early, J.V.; Alling, T.; Bowman, J.; Zuniga, E.S.; Dalai, S.; Kumar, N.; Masquelin, T.; et al. Synthesis and Evaluation of the 2-Aminothiazoles as Anti-Tubercular Agents. PLoS ONE 2016, 11, e0155209. [CrossRef]

27. Meissner, A.; Boshoff, H.; Barry, C., III; Aldrich, C. Structure-activity relationships of 2-aminothiazoles effective against Mycobacterium tuberculosis. Bioorg. Med. Chem. 2013, 21, 6385. [CrossRef]

28. Wang, X.J.; Yang, Q.; Liu, F.; You, Q.D. Microwave-Assisted Synthesis of Amide under Solvent-free Conditions. Synth. Commun. 2008, 38, 1028-1035. [CrossRef]

29. Torres-Jaramillo, J. Síntesis de Bioisósteros de N-Acilhomoserin Lactonas para su Evaluación en Serratia marcescens. Master's Thesis, ENCB, IPN, Ciudad de México, Mexico, 2017.

30. Ueda, F.; Ueda, T.; Toyoshima, S. Syntheses and Antimicrobial Activity of 2-Acylaminothiazole-carboxylic Acid and its Related Compounds. Yakugaku Zasshi 1959, 79, 925-930. [CrossRef]

31. Krishna-Mohan, K.; Narender, N.; Kulkarni, S. Zeolite catalyzed acylation of alcohols and amines with acetic acid under microwave irradiation. Green Chem. 2006, 8, 368. [CrossRef]

32. Trose, M.; Lazreg, F.; Cazin, C. A straightforward metal-free synthesis of 2-substituted thiazolines in air. Green Chem. 2015, 17, 3090. [CrossRef]

33. Maltsev, O.V.; Walter, V.; Brandl, M.J.; Hintermann, L. Medium buffer effects on the condensation of L-cysteine and aryl nitriles to (R)-2-aryl-4, 5-dihydrothiazole-4-carboxylic acids. Synthesis 2013, 45, 2763-2767. [CrossRef]

34. Berteotti, A.; Vacondio, F.; Mor, M.; Cavalli, A. Predicting the Reactivity of Nitrile-Carrying Compounds with Cysteine: A Combined Computational and Experimental Study. ACS Med. Chem. Lett. 2014, 5, 501. [CrossRef] [PubMed]

35. Ojeda-Porras, A.; Hernández-Santana, A.; Gamba-Sánchez, D. Direct Amidation of Carboxylic Acids with Amines under Microwave Irradiation Using Silica Gel as a Solid Support. Green Chem. 2015, 17, 3157. [CrossRef]

36. Allen, L.; Chhatwal, R.; Williams, J. Transamidation of primary amides with amines catalyzed by zirconocene dichloride. Chem. Commun. 2012, 48, 666. [CrossRef] [PubMed]

37. Mavrova, A.T.; Anichina, K.K.; Vuchev, D.I.; Tsenov, J.A.; Kondeva, M.S.; Micheva, M.K. Synthesis and antitrichinellosis activity of some 2-substituted-[1,3]thiazolo[3,2-a]benzimidazol-3(2H)-ones. Bioorg. Med. Chem. 2005, 13, 5550-5559. [CrossRef] 
38. Bellebeni, M.; Ballini, R.; Predieri, G.; Sartori, G. Synthesis of Symmetrical N,N\$-Disubstituted Thioureas and Heterocyclic Thiones from Amines and $\mathrm{CS}_{2}$ over a $\mathrm{ZnO} / \mathrm{Al}_{2} \mathrm{O}_{3}$ Composite as Heterogeneous and Reusable Catalyst. J. Org. Chem. 1999, 64, 1029. [CrossRef]

39. Maheshwari, N.; Karthikeyan, C.; Bhadada, S.V. Design, synthesis and biological evaluation of some tetrazole acetamide derivatives as novel non-carboxylic PTP1B inhibitors. Bioorg. Chem. 2019, 92, 103221. [CrossRef]

40. Ahamed, A.J.; Kaliapillai, N.V.; Bathey, R.V.; Govindaraj, V. Synthesis, characterization and biological activity of some novel benzimidazole derivatives. Orbital 2009, 1, 306-309. [CrossRef]

41. Srinivasarao, S.; Nizalapur, S.; Yu, T.T.; Pulya, S.; Ghosh, B.; Murugesan, S.; Kumar, N.; Sekhar, K.V.G.C. Design, synthesis and biological evaluation of 1,2,3-triazole based 2-aminobenzimidazoles as novel inhibitors of LasR dependent quorum sensing in Pseudomonas aeruginosa. RSC Adv. 2019, 9, 29273. [CrossRef]

42. Lima, C.B.A.; Espínola, J.; de Oliveira, S.F.; Arakaki, L.N.H.; Fonseca, M.G.; Airoldi, C. Synthesis, characterization and thermal behavior of cobalt(II) 5-chloro-piridylamides complexes. Thermochim. Acta. 2003, 407, 117-120. [CrossRef]

43. Colanceska-Ragenovic, K.; Ilievska, S.; Prendov, S.; Dimova, V.; Stamatovska, V. Synthesis of some $\mathrm{N}$-arylnonanamides and investigation of their effects in the process of bleaching of cotton yarns with $\mathrm{H}_{2} \mathrm{O}_{2}$. Vlak. Textil. 2003, 10, 17-20.

44. Bucio-Cano, A. Síntesis de Azolinas, su Evaluación en la Inhibición del quorum sensing y Mecanismo de Acción. Master's Thesis, ENCB, IPN, Ciudad de México, Mexico, 2015.

45. Rasmussen, T.B.; Bjarnsholt, T.; Skindersoe, M.E.; Hentzer, M.; Kristoffersen, P.; Köte, M. Screening for Quorum-Sensing Inhibitors (QSI) by use of a novel genetic system, the QSI selector. J. Bacteriol. 2005, 187, 1799-1814. [CrossRef] [PubMed]

46. Forschner-Dancause, S.; Poulin, E.; Meschwitz, S. Quorum Sensing Inhibition and Structure-Activity Relationships of $\beta$-Keto Esters. Molecules 2016, 21, 971. [CrossRef] [PubMed]

47. Morris, G.M.; Huey, R.; Lindstrom, W.; Sanner, M.F.; Belew, R.K.; Goodsell, D.S.; Olson, A.J. AutoDock4 and AutoDockTools4: Automated docking with selective receptor fexibility. J. Comput. Chem. 2009, 30, 2785-2791. [CrossRef] [PubMed]

48. DeLano, W.L. The PyMOL Molecular Graphics System; Schrodinger, L., Ed.; Schrödinger, LLC: New York, NY, USA, 2002.

49. Torres-Jaramillo, J.; Bautista-Hernández, J.; Soriano-Chávez, C.; Curiel-Quesada, E.; Reyes-Arellano, A. Ultrasound and MW assisted synthesis of azoles and azolines. Biological evaluation in Serratia marcescens. 2020; Manuscript in preparation.

50. Damien, M.; Laurence, G.R. Pharmacological Inhibition of the Pseudomonas aeruginosa MvfR Quorum-Sensing System Interferes with Biofilm Formation and Potentiates Antibiotic-Mediated Biofilm Disruption. Antimicrob. Agents Chemother. 2017, 61, e01362-17. [CrossRef]

51. ACD/ChemSketch, Version 14.01; Advanced Chemistry Development, Inc.: Toronto, ON, Canada, 2012.

52. Frisch, M.J.; Trucks, G.W.; Schlegel, H.B.; Scuseria, G.E.; Robb, M.A.; Cheeseman, J.R.; Fox, D.J. Gaussian 09, Version 09; Gaussian Inc.: Wallingford, CT, USA, 2009.

Publisher's Note: MDPI stays neutral with regard to jurisdictional claims in published maps and institutional affiliations.

(C) 2020 by the authors. Licensee MDPI, Basel, Switzerland. This article is an open access article distributed under the terms and conditions of the Creative Commons Attribution (CC BY) license (http://creativecommons.org/licenses/by/4.0/). 